\title{
Evaluating Barrier Island Characteristics and Piping Plover (Charadrius melodus) Habitat Availability Along the U.S. Atlantic Coast- Geospatial Approaches and Methodology
}

Open-File Report 2019-1071

Version 1.1, October 2019 



\section{Evaluating Barrier Island Characteristics and Piping Plover (Charadrius melodus) Habitat Availability Along the U.S. Atlantic Coast-Geospatial Approaches and Methodology}

By Sara L. Zeigler, Emily J. Sturdivant, and Benjamin T. Gutierrez

Open-File Report 2019-1071

Version 1.1, October 2019 


\title{
U.S. Department of the Interior DAVID BERNHARDT, Secretary
}

\section{U.S. Geological Survey James F. Reilly II, Director}

\author{
U.S. Geological Survey, Reston, Virginia: 2019 \\ First release: 2019 \\ Revised: October 2019 (ver 1.1)
}

\begin{abstract}
For more information on the USGS - the Federal source for science about the Earth, its natural and living resources, natural hazards, and the environment-visit https://www.usgs.gov or call 1-888-ASK-USGS.

For an overview of USGS information products, including maps, imagery, and publications, visit https://store.usgs.gov.
\end{abstract}

\footnotetext{
Any use of trade, firm, or product names is for descriptive purposes only and does not imply endorsement by the U.S. Government.

Although this information product, for the most part, is in the public domain, it also may contain copyrighted materials as noted in the text. Permission to reproduce copyrighted items must be secured from the copyright owner.

Suggested citation:

Zeigler, S.L., Sturdivant, E.J., and Gutierrez, B.T., 2019, Evaluating barrier island characteristics and piping plover (Charadrius melodus) habitat availability along the U.S. Atlantic coast-Geospatial approaches and methodology (ver. 1.1, October 2019): U.S. Geological Survey Open-File Report 2019-1071, 34 p., https://doi.org/10.3133/ ofr20191071.

ISSN 2331-1258 (online)
} 


\section{Acknowledgments}

This work was supported by the U.S. Department of the Interior's Hurricane Sandy recovery program under the Disaster Relief Appropriations Act of 2013 (Public Law 113-2, 127 Stat. 4), the U.S. Geological Survey (USGS) Coastal and Marine Geology Program, the U.S. Fish and Wildlife Service, and the North Atlantic Landscape Conservation Cooperative. A. Hecht of the U.S. Fish and Wildlife Service and A. Milliken, previously of the North Atlantic Landscape Conservation Cooperative, provided motivation for this research. We thank Federal and private collaborators who supervised, participated in, and coordinated field-testing and data collection in the iPlover smartphone application. H. Abouelezz of the U.S. National Park Service provided spatial data for the Breezy Point Unit of the Gateway National Recreation Area that were used in generating geospatial datasets for that study location. K. Weber of the USGS provided analyses of shoreline and dune characteristics for select New York, Massachusetts, Rhode Island, and Maine study areas. Finally, we appreciate reviews of this report by E. Pendleton and Z. Defne, both of the USGS. 



\section{Contents}

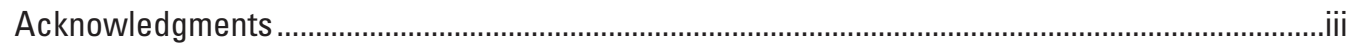

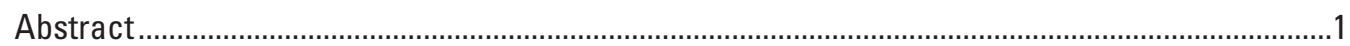

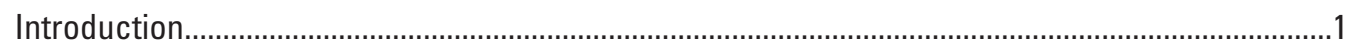

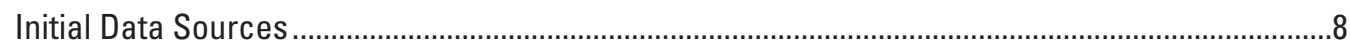

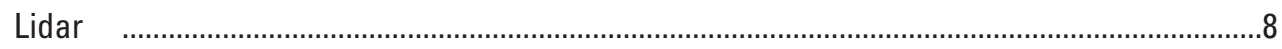

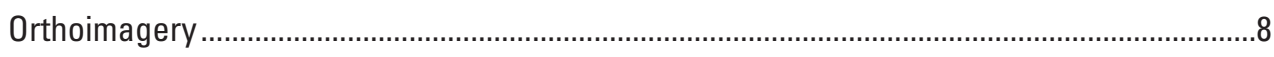

National Assessment of Shoreline Change Transects .........................................................

Mean High Water Offsets ......................................................................................................

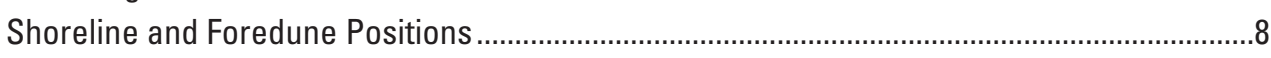

Methods_-Barrier Island Geomorphology Bayesian Network ....................................................

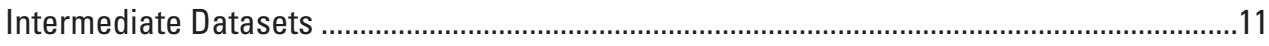

Supplemented Transects ...................................................................................11

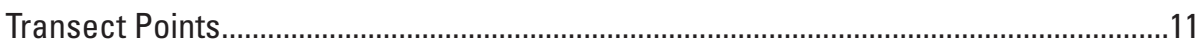

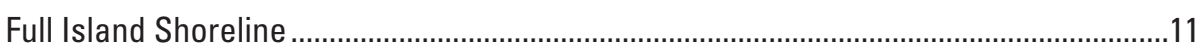

Bayesian Network Datasets: Transect-Averaged Metrics....................................................13

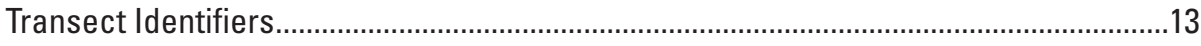

Shoreline Change Rates ....................................................................................... 13

Beach Width and Height ........................................................................................13

Mean High Water Position and Foreshore Slope Along Transect..........................13

Foredune Positions and Elevations Along Transects.............................................13

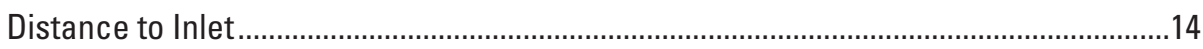

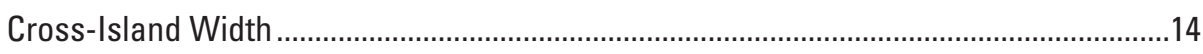

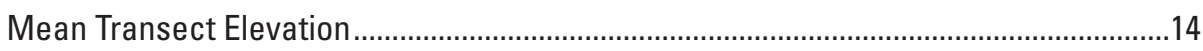

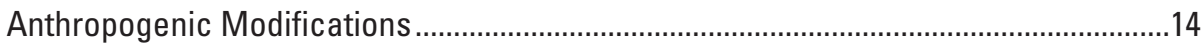

Bayesian Network Datasets: 5-Meter Point Metrics ……………………………..................17

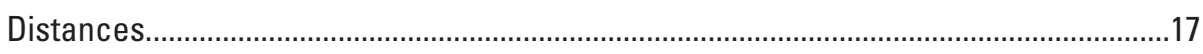

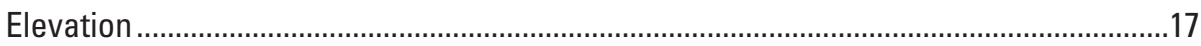

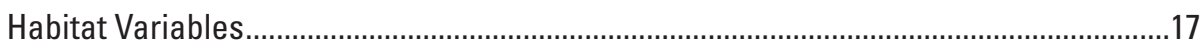

Methods_-Piping Plover Habitat Bayesian Network ……….........................................................

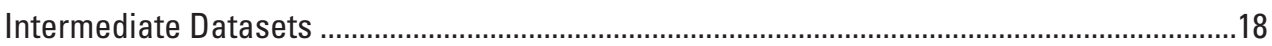

Supervised Land Cover Classification...........................................................................18

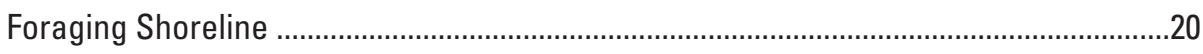

Movement Cost Layer ..................................................................................................

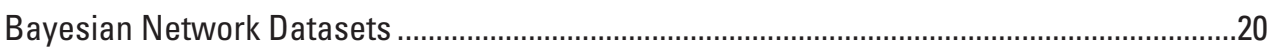

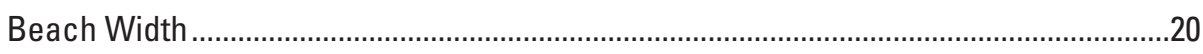

Elevation (Corrected for Mean High Water)................................................................22

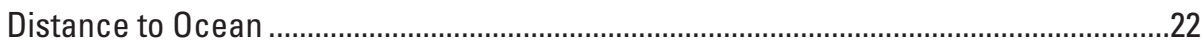

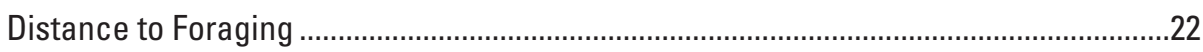

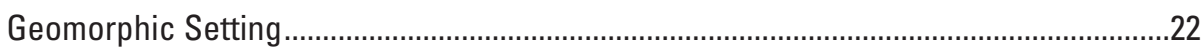

Substrate Type

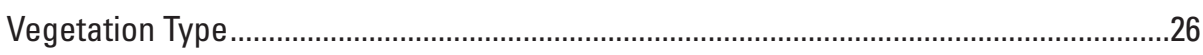

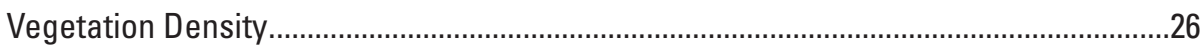

Validation of Select Bayesian Network Datasets ....................................................................2

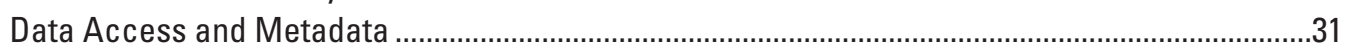

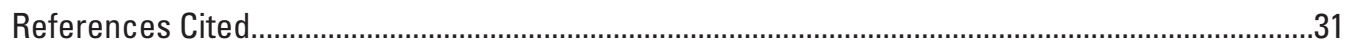




\section{Figures}

1. Diagram showing separate Bayesian networks developed for shoreline change (as affected by sea-level rise), barrier island geomorphology, and piping plover habitat availability.....

2. Map showing study areas for which coastal metrics and spatial datasets were created for use in modeling barrier island biogeomorphological characteristics and piping plover habitat availability along the U.S. Atlantic coast.....

3. Flowchart showing $A$, summary workflow for deriving Bayesian networks (BNs) from initial data sources. $B$, Initial data sources together are used to create intermediate datasets. Both initial data and intermediate datasets are used as inputs in the $C$, transect-averaged metrics and $D$, point metrics versions of the Barrier Island Geomorphology BN and the E, Piping Plover Habitat BN

4. Maps showing examples of the types of data sources and products presented in this report, depicting a section of Fire Island, New York

5. Diagram of barrier island metrics

6. Aerial orthoimagery illustrating the four categories of anthropogenic development considered in this study: $A$, none, $B$, light, $C$, moderate, and $D$, heavy

7. Maps showing masks and training polygons used as part of the supervised classification for each study area

8. Maps showing examples of final products used in the Piping Plover Habitat Bayesian network, depicting raster coverages for $A$, beach width, $B$, elevation, $C$, distance from ocean, and $D$, distance to foraging for Pullen and Long Beach Islands, New Jersey

9. Maps showing examples of hand-digitized polygons depicting geomorphic settings

10. Maps showing examples of raster datasets for $A$, substrate type, $B$, vegetation type, and $C$, vegetation density for the Rockaway Peninsula, New York

\section{Tables}

1. Summary of variables for which Bayesian network datasets were created for each study area for use in the Barrier Island Geomorphology and Piping Plover Habitat

Bayesian networks.

2. Initial data sources by study area and year used to derive inputs to the Barrier Island Geomorphology and Piping Plover Habitat Bayesian networks.

3. Mean high water corrections and Universal Transverse Mercator zone, by study area, used to derive inputs to the Barrier Island Geomorphology and Piping Plover Habitat Bayesian networks

4. Definitions of categorical variables used to describe land cover characteristics associated with piping plover habitat and nonhabitat in the Barrier Island Geomorphology and Piping Plover Habitat Bayesian networks

5. Reclassification values used to translate the original supervised classification to raster layers depicting substrate type, vegetation type, and vegetation density

6. Study areas and associated data points used to validate spatial analyses that resulted in raster layers for geomorphic setting, substrate type, vegetation type, and vegetation density. 
7. Contingency table for validating geomorphic setting raster layers created for each study area used to validate spatial analyses...

8. Contingency table for validating substrate type raster layers created for each study area used to validate spatial analyses.

9. Contingency table for validating vegetation type raster layers created for each study area used to validate spatial analyses

10. Contingency table for validating vegetation density raster layers created for each study area used to validate spatial analyses

\section{Conversion Factors}

International System of Units to U.S. customary units

\begin{tabular}{lll}
\hline \multicolumn{1}{c}{ Multiply } & \multicolumn{1}{c}{ By } & \multicolumn{1}{c}{ To obtain } \\
\hline millimeter $(\mathrm{mm})$ & 0.03937 & inch (in.) \\
meter $(\mathrm{m})$ & 3.281 & foot $(\mathrm{ft})$ \\
kilometer $(\mathrm{km})$ & 0.6214 & mile $(\mathrm{mi})$ \\
\hline
\end{tabular}

\section{Datum}

Vertical coordinate information is referenced to the North American Vertical Datum of 1988 (NAVD 88) unless otherwise stated.

Horizontal coordinate information is referenced to the North American Datum of 1983 (NAD 83). UTM zone is dependent on study area location.

Elevation, as used in this report, refers to distance above NAVD 88 or local mean high water.

\section{Abbreviations}

$\begin{array}{ll}\text { BN } & \text { Bayesian network } \\ \text { DEM } & \text { digital elevation model } \\ \text { GNSS } & \text { Global Navigation Satellite System } \\ \text { ID } & \text { identification } \\ \text { lidar } & \text { light detection and ranging } \\ \text { MHW } & \text { mean high water } \\ \text { MLW } & \text { mean low water } \\ \text { MTL } & \text { mean tidal level } \\ \text { NASC } & \text { [USGS] National Assessment of Shoreline Change } \\ \text { NOAA } & \text { National Oceanic and Atmospheric Administration } \\ \text { SLR } & \text { sea-level rise } \\ \text { USGS } & \text { U.S. Geological Survey }\end{array}$





\title{
Evaluating Barrier Island Characteristics and Piping Plover (Charadrius melodus) Habitat Availability Along the U.S. Atlantic Coast-Geospatial Approaches and Methodology
}

\author{
By Sara L. Zeigler, Benjamin T. Gutierrez, and Emily J. Sturdivant
}

\begin{abstract}
Policy makers, individuals from government agencies, and natural resource managers face increasing demands to manage coastal areas in a way that meets economic, social, and ecological needs as sea levels rise. Scientific knowledge of how coastal processes drive beach and barrier island changes and how those changes affect habitat use can support decision makers as they balance sometimes conflicting human and ecological needs. However, uncertainties in the knowledge of the cumulative results of coastal processes make it challenging to forecast specific changes for a particular location and time. The U.S. Geological Survey is developing tools for identifying and forecasting barrier island characteristics as well as suitable coastal habitats for species of concern (such as piping plovers, Charadrius melodus) given ongoing sea-level rise. As part of this effort, we use three Bayesian networks to calculate probabilities of shoreline change rates, changes in barrier island biogeomorphic characteristics, and piping plover habitat availability, which together forecast the effects of different sea-level-rise rates and storm regimes. This report details the methodology used to derive geospatial biogeomorphic datasets that are used as inputs for two of these Bayesian networks, which forecast barrier island geomorphology and piping plover habitat availability at sites along the U.S. Atlantic coast (Maine to North Carolina). Further information about the project, including specific study sites, can be found at https://woodshole.er.usgs.gov/project-pages/ beach-dependent-shorebirds/.
\end{abstract}

\section{Introduction}

Sea-level rise (SLR), which is associated with climate change-induced thermal expansion of ocean waters and melting of land-based ice masses, is of particular concern given that 10 percent of the world's population resides in low-elevation coastal regions (McGranahan and others, 2007; Church and others, 2013). SLR will likely affect millions of people in the United States alone (Hauer and others, 2016). Although estimating the magnitude of SLR and its effects is challenging because of uncertainties in ice-sheet contributions to SLR and in levels of future greenhouse gas emissions, most projections estimate that seas will rise by between 0.4 and 1.5 meters $(\mathrm{m})$ in many parts of the world by 2100 (Nicholls and Cazenave, 2010; Church and others, 2013; Kopp and others, 2016; Sweet and others, 2017). Some regions may experience greater relative SLR as a result of variations in circulation, temperature, salinity, subsidence, and human activities (Braatz and Aubrey, 1987; Gornitz and Lebedeff, 1987; Sallenger and others, 2012; Church and others, 2013; Sweet and others, 2017). SLR is predicted to cause the submergence of low-lying coastal regions, saltwater intrusion into freshwater systems and groundwater, and increased coastal erosion and flooding (Titus and others, 2009; Nicholls and Cazenave, 2010; Melillo and others, 2014). SLR will have consequences for biodiversity, particularly on islands and in other low-elevation coastal ecoregions (Galbraith and others, 2002; Menon and others, 2010; Courchamp and others, 2014). Therefore, SLR vulnerability assessments for coastal regions are critical for informing appropriate responses to rising seas, such as protection, adaptation, or planned retreat.

Barrier islands make up large parts of the U.S. Atlantic and Gulf coasts, from New England to the United StatesMexico border in Texas. Barrier islands and coastal ecosystems are dynamic landforms that are in a continual state of change in response to SLR, storms, passing weather systems, evolving sediment budgets, and cyclical patterns of inlet migration (Leatherman, 1983; Oertel, 1985; Davis, 1994; Morton and others, 1994; Morton and Sallenger, 2003; FitzGerald and others, 2008). Many of these landforms have high human population densities and lucrative tourism and recreational opportunities while providing critical ecosystem services and habitats (U.S. Commission on Ocean Policy, 2004). Weighing the importance of natural ecosystem and landform function against human interests is a persistent challenge for coastal managers. Thus, understanding the potential 
effects of SLR on coastal landforms and the species and habitats they support will be critical for designing mitigation and management approaches that balance the needs of humans and native species.

The federally protected piping plover (Charadrius melodus) is one species expected to be directly and indirectly affected by SLR (U.S. Fish and Wildlife Service, 2014). The Atlantic coast population of piping plovers nests on beaches and barrier islands along the Atlantic coast of North America. This species requires a complex balance of habitat characteristics that minimize threats from disturbance, predation, and competition. Nesting typically occurs on flat, low-lying, minimally vegetated dry sand or pebble beaches in areas that are beyond the high-tide line but near moist substrate foraging habitat (Cohen and others, 2008; Maslo and others, 2011; Zeigler and others, 2017). Such areas are expected to be among the most affected by SLR (Gutierrez and others, 2007; Titus and others, 2009; Lentz and others, 2016). Although it is widely recognized that long-term effects of SLR and storms will affect beach and barrier island settings - and consequently piping plover habitat — quantitative estimates of habitat effects have been limited because of the complexity and uncertainty associated with forcing factors. In addition, nesting habitat is often found in areas that are attractive for commercial and residential development. However, development and the demand for measures to protect such human investment from SLR and extreme weather events are often at odds with this species' nesting habitat preferences (reviewed in Gieder and others, 2014).

Given the increasing need to develop the capability to forecast SLR effects on barrier islands in the near- and longterm, we developed three Bayesian networks (BNs; fig. 1) to evaluate and forecast SLR-driven shoreline changes, barrier island characteristics, and piping plover habitat availability for sites along the U.S. Atlantic coast (Maine to North Carolina; fig. 2). The first, the Shoreline Change BN, models shoreline position as a function of processes such as SLR and waves (Gutierrez and others, 2011, 2014). Methodology related to the Shoreline Change BN is detailed in Gutierrez and others (2011, 2014). The second, the Barrier Island Geomorphology $\mathrm{BN}$, is based on earlier work by Gutierrez and others (2015) and evaluates the probability of select physical characteristics of barrier island settings. The third, the Piping Plover Habitat BN (Zeigler and others, 2017), is built on the work of Gieder and others (2014) to evaluate the probability of suitable piping plover nesting conditions at sites throughout the species' U.S. Atlantic coast breeding range.

This report details the methods used to create input datasets for the Barrier Island Geomorphology BN and the Piping Plover Habitat BN (fig. 1). We use three terms to describe the data in our workflow (fig. 3): initial data sources (fig. 4), such as elevation and imagery; intermediate datasets, which we produced and used to derive final products used in the BNs; and BN datasets, which are the spatial datasets and variables used directly as inputs to the BNs (table 1). To create the datasets ultimately used in the BNs, we (1) compiled initial datasets from external sources, (2) derived intermediate datasets, (3) sampled geomorphology variables (for example, beach width, mean island elevation) along shore-normal transects spanning the width of the barrier island, (4) extracted finer scale barrier island characteristics (for example, substrate type, elevation) at points spaced at 5-m intervals along shorenormal transects, and (5) created raster datasets (5-m resolution) describing barrier island characteristics relevant to piping plover nesting habitat (fig. 3).

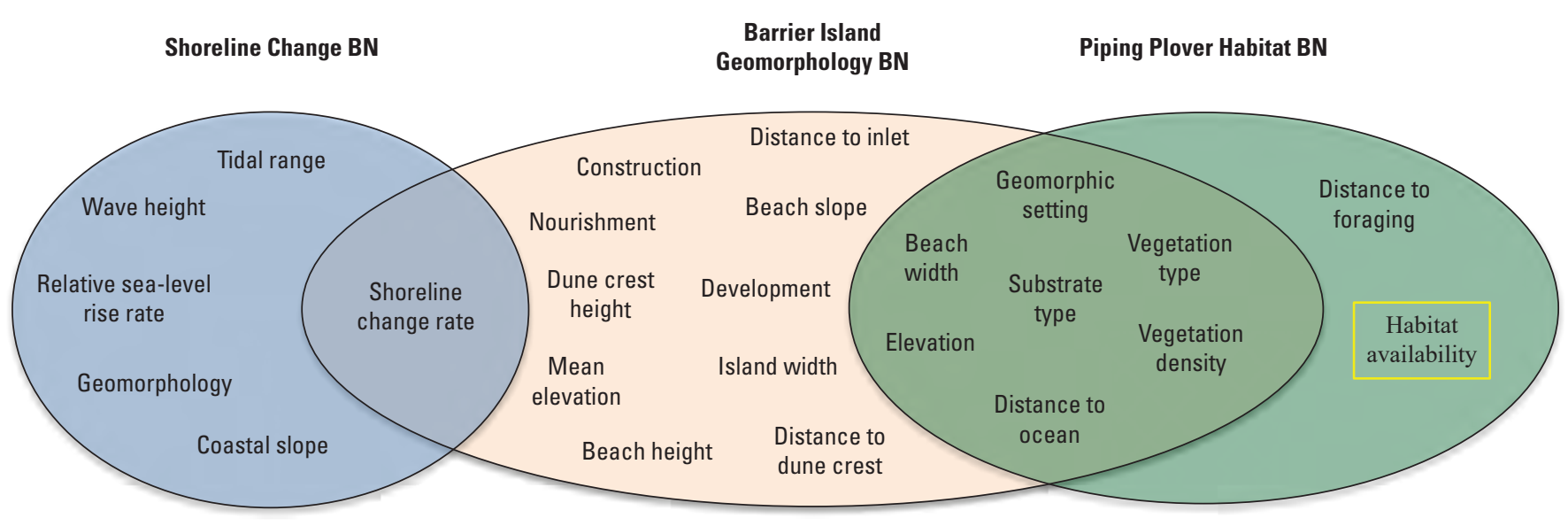

Figure 1. Separate Bayesian networks developed for shoreline change (as affected by sea-level rise), barrier island geomorphology, and piping plover habitat availability. These networks can operate as stand-alone, discipline-specific models, or they can be linked through the parameters in overlapping regions of the model ovals in this figure to evaluate the effects of processes like sea-level rise on piping plover habitat availability. 


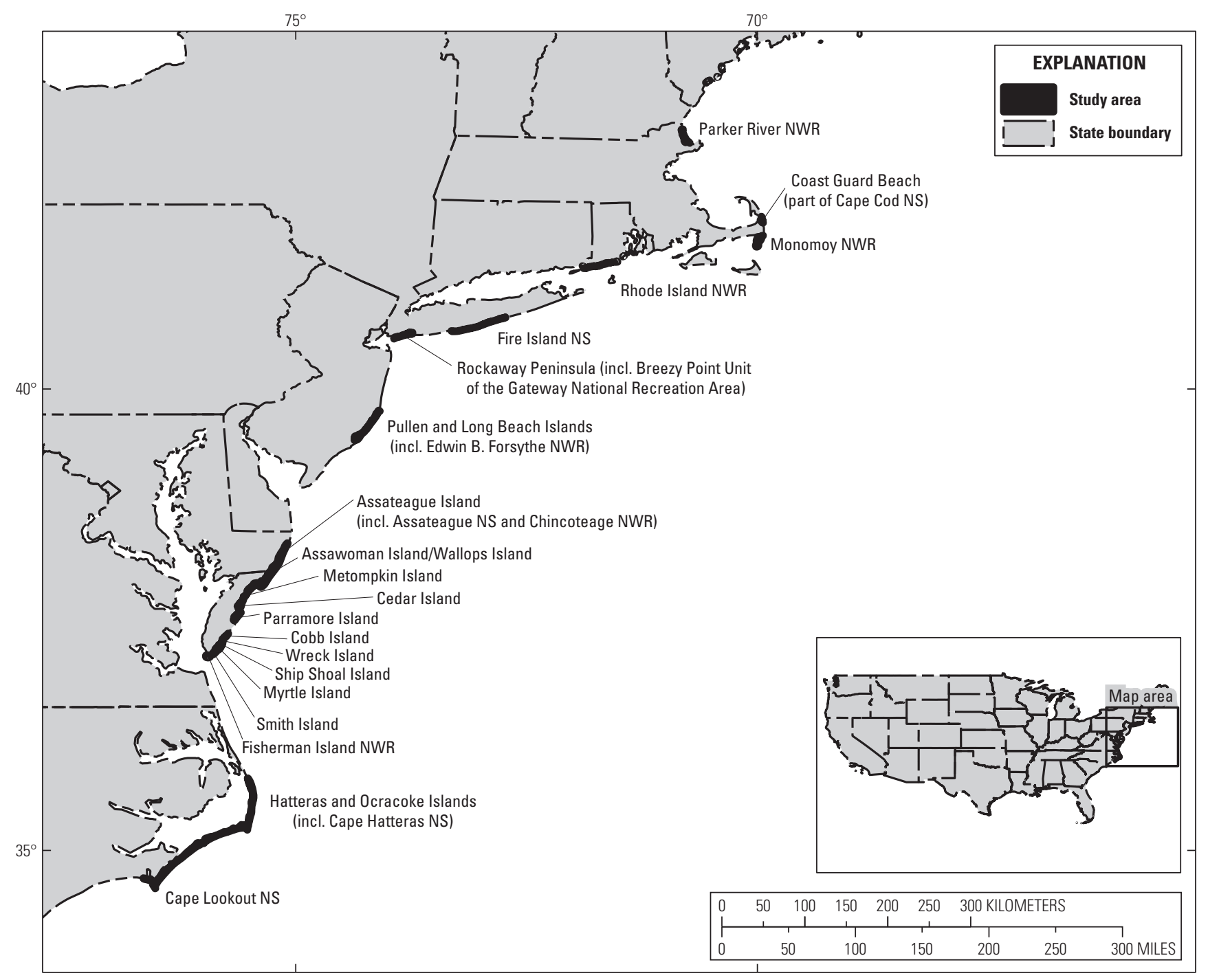

Figure 2. Study areas for which coastal metrics and spatial datasets were created for use in modeling barrier island biogeomorphological characteristics and piping plover habitat availability along the U.S. Atlantic coast. Study areas are shown in black and labeled in text; incl., including; km, kilometer; NS, National Seashore; NWR, National Wildlife Refuge. 

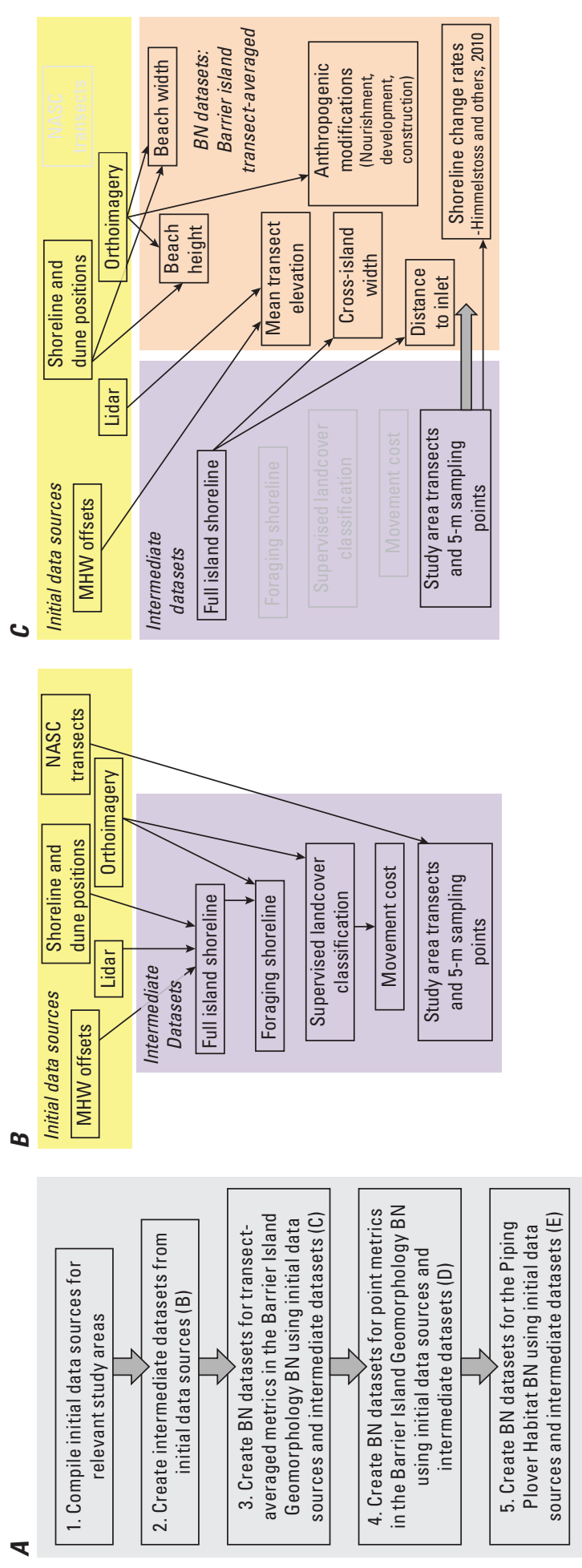
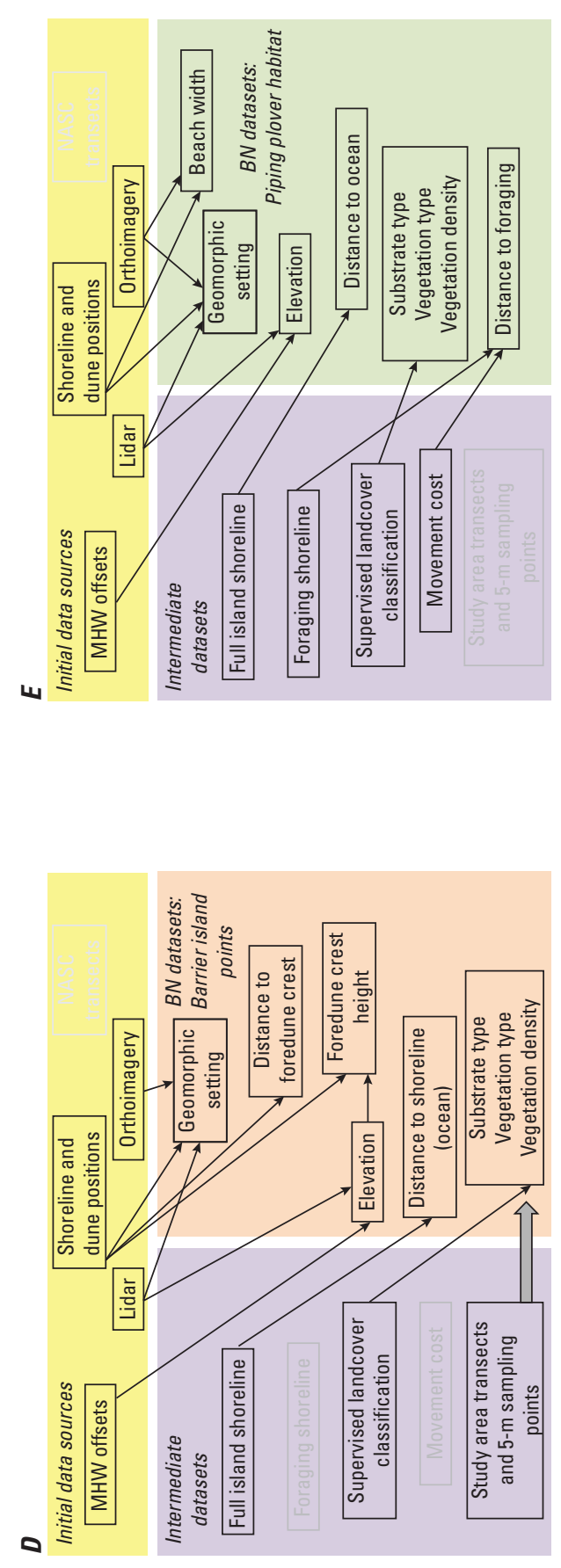

兽 0. 웡

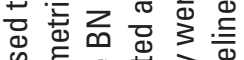
乌

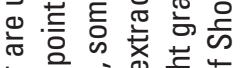

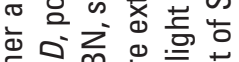

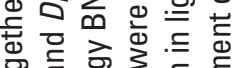
营

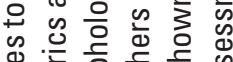

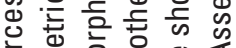

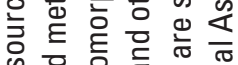
क

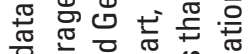

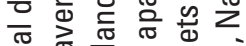

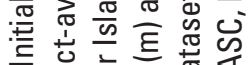

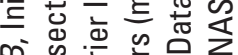
i 过

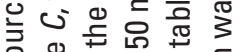
कि

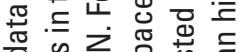

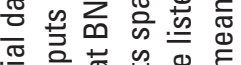
西

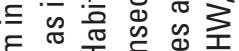

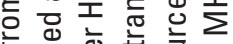

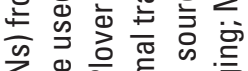

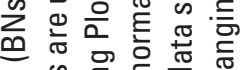

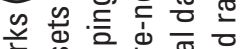

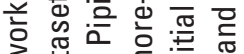
要求的空

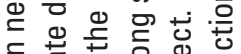
든. 흠 흥 d

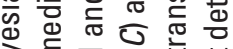

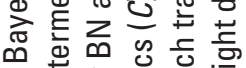

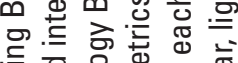

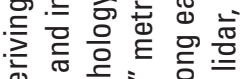

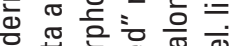

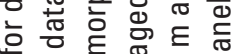
制

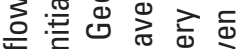
흔

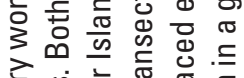

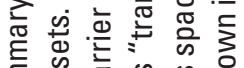

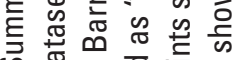

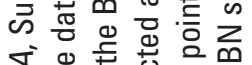

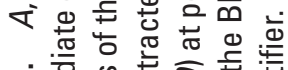
m 후을 힌 응웡

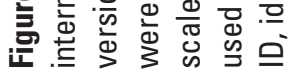




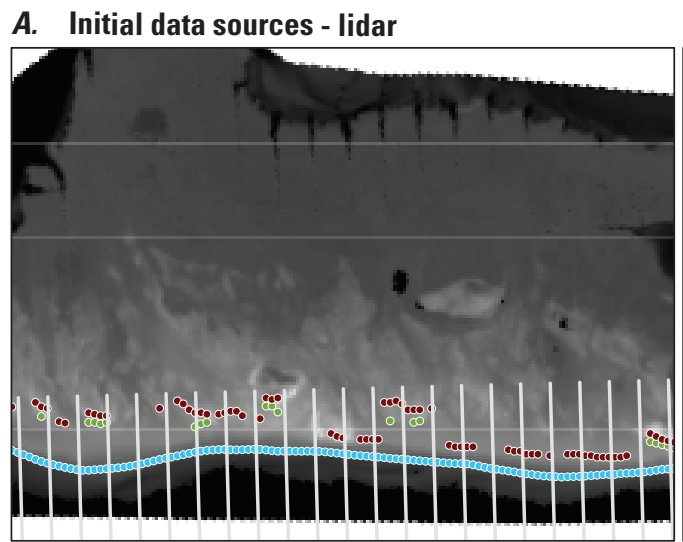

B. Initial data sources - orthoimagery

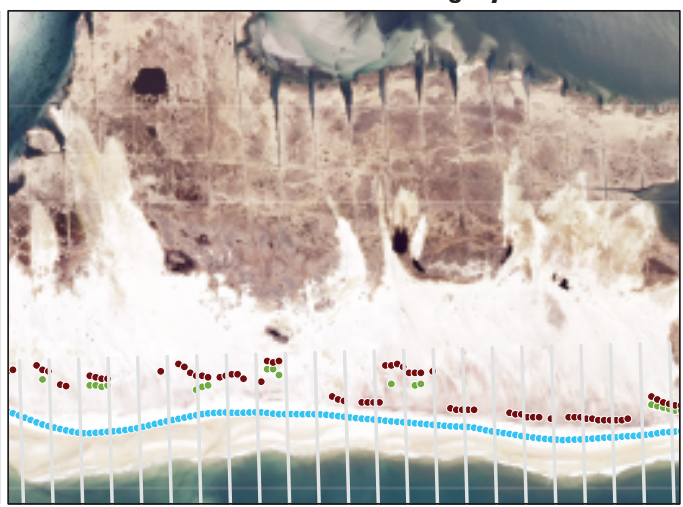

C. Intermediate datasets

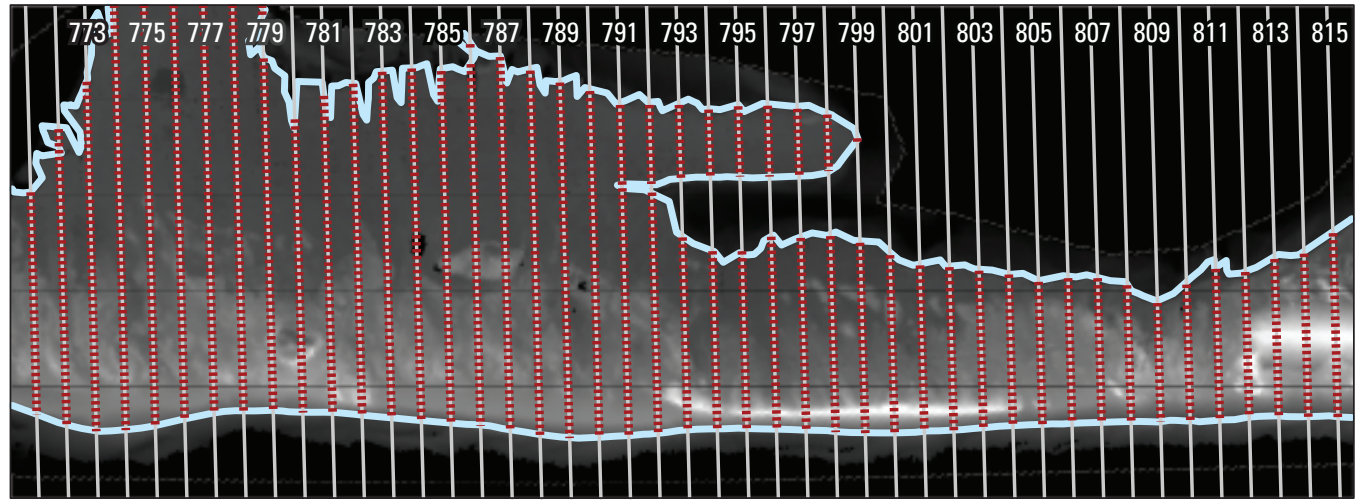

D. BN datasets

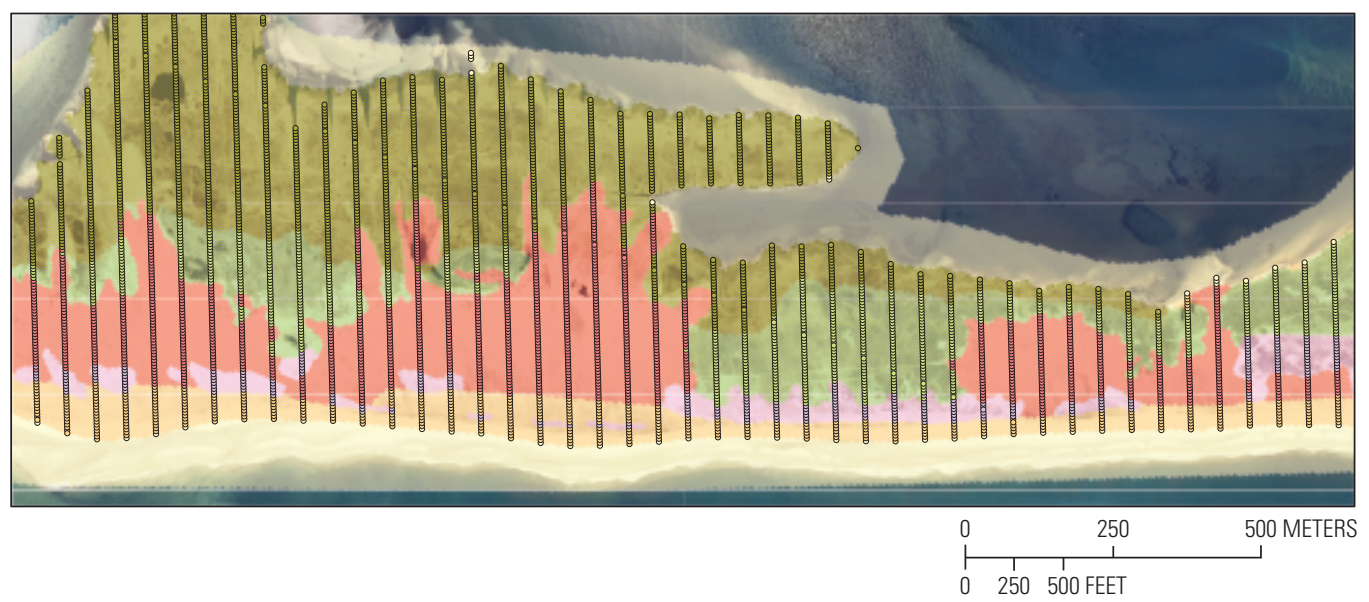

EXPLANATION

NASC transects

- Dune crest

- Dune toe

- MHW shoreline

Elevation (m)

5

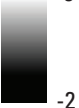

2

\section{EXPLANATION}

$=5-\mathrm{m}$ points (along transects)

- Supplemented NASC transects (labeled by ID)

Shoreline polygon

\section{EXPLANATION}

Geomorphic setting

Beach

Backshore

Dune complex

Washover

Barrier interior

Marsh

Figure 4. Examples of the types of data sources and products presented in this report, depicting a section of Fire Island, New York. Initial data sources included $A$, light detection and ranging (lidar)-derived digital elevation models and $B$, orthoimagery for National Assessment of Shoreline Change (NASC) sampling transects (gray lines; Himmelstoss and others, 2010) and shoreline and foredune metrics (colored points; Doran and others, 2017). $C$, Intermediate datasets, such as the full island shoreline, were derived from initial data sources. $D$, Bayesian network (BN) datasets, such as the geomorphic settings raster coverage, were derived from a combination of initial data sources and intermediate datasets. BN datasets were used as inputs for the Barrier Island Geomorphology and Piping Plover Habitat BNs. ID, identification number; $m$, meter; MHW, mean high water. 
Table 1. Summary of variables for which Bayesian network datasets were created for each study area for use in the Barrier Island Geomorphology and Piping Plover Habitat Bayesian networks.

[Text in parentheses next to each variable name is the abbreviated name used for that variable in Sturdivant and others (2019). Further information about the project, including specific study sites, can be found at https://woodshole.er.usgs.gov/project-pages/beach-dependent-shorebirds/. Values in datasets used in the Barrier Island Geomorphology Bayesian network (BN) were measured at points spaced every 5 meters $(\mathrm{m})$ along shore-normal transects, which occurred every $50 \mathrm{~m}$ along the length of a given barrier island or study area. Values in datasets used in the Piping Plover Habitat BN were measured within 5- $\times 5$-m raster grid cells spanning the entire barrier island or study area. MHW, mean high water]

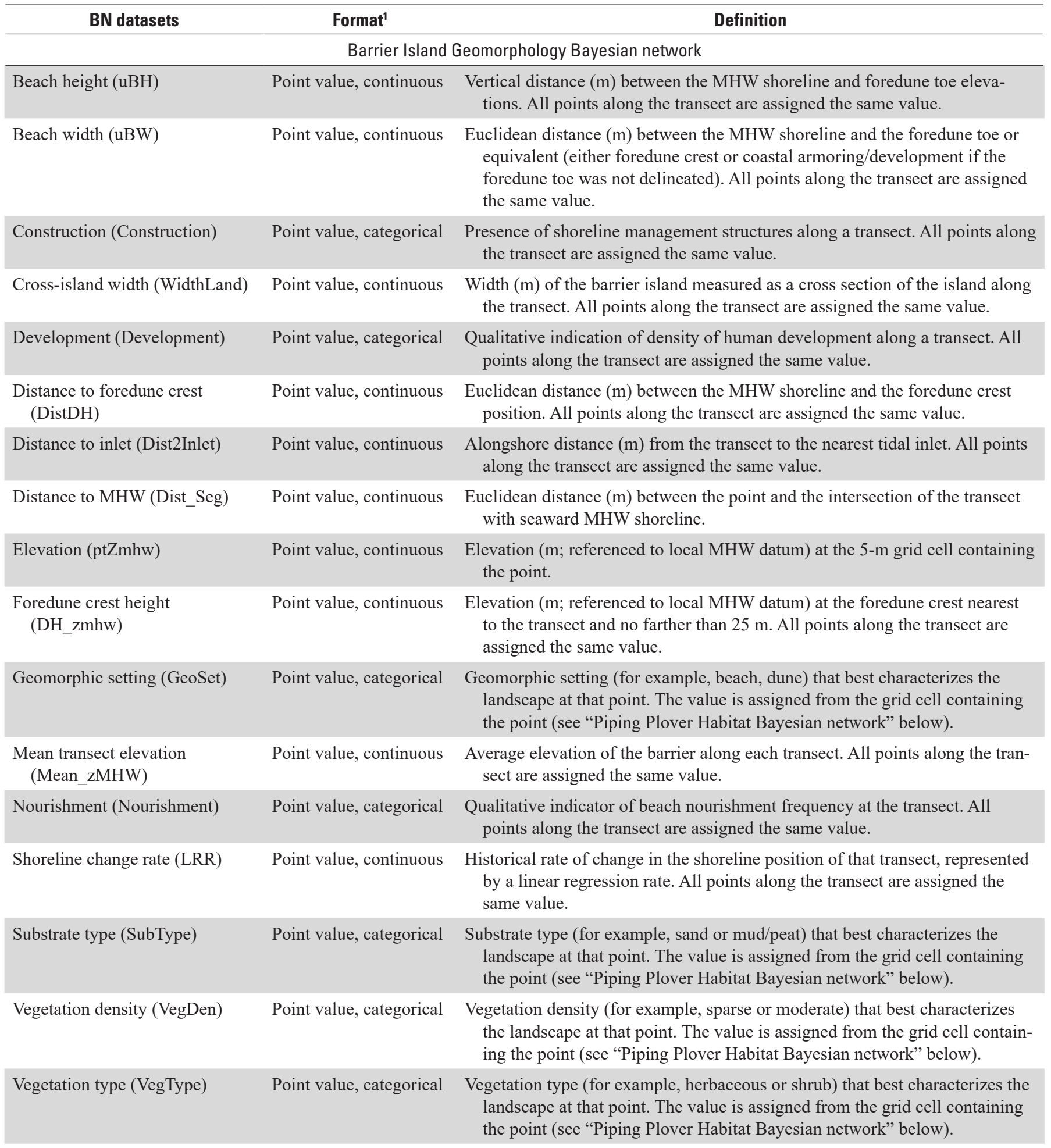


Table 1. Summary of variables for which Bayesian network datasets were created for each study area for use in the Barrier Island Geomorphology and Piping Plover Habitat Bayesian networks. - Continued

[Text in parentheses next to each variable name is the abbreviated name used for that variable in Sturdivant and others (2019). Further information about the project, including specific study sites, can be found at https://woodshole.er.usgs.gov/project-pages/beach-dependent-shorebirds/. Values in datasets used in the Barrier Island Geomorphology Bayesian network $(\mathrm{BN})$ were measured at points spaced every 5 meters $(\mathrm{m})$ along shore-normal transects, which occurred every $50 \mathrm{~m}$ along the length of a given barrier island or study area. Values in datasets used in the Piping Plover Habitat BN were measured within 5- $\times 5$-m raster grid cells spanning the entire barrier island or study area. MHW, mean high water]

\begin{tabular}{|c|c|c|}
\hline BN datasets & Format $^{1}$ & Definition \\
\hline \multicolumn{3}{|c|}{ Piping Plover Habitat Bayesian network } \\
\hline Beach width (BW) & Raster layer, continuous & $\begin{array}{l}\text { Width }(\mathrm{m}) \text { of the beach (from MHW shoreline to foredune toe or equivalent) } \\
\text { at the nearest shore-normal transect. The value is assigned from the transect } \\
\text { nearest to the grid cell (see "Barrier Island Geomorphology Bayesian } \\
\text { network" above). }\end{array}$ \\
\hline Distance to foraging (DisMOSH) & Raster layer, continuous & $\begin{array}{l}\text { Least cost distance }(\mathrm{m}) \text { from the center of the cell to the nearest non-ocean } \\
\text { foraging area containing moist substrates. }\end{array}$ \\
\hline Distance to ocean (DisOcean) & Raster layer, continuous & $\begin{array}{l}\text { Euclidean distance }(\mathrm{m}) \text { from the center of the cell to the nearest point on the } \\
\text { ocean MHW shoreline. }\end{array}$ \\
\hline Elevation (ElevMHW) & Raster layer, continuous & Elevation (m) referenced to $\mathrm{MHW}$. \\
\hline Geomorphic setting (GeoSet) & Raster layer, categorical & Major geomorphic feature (for example, beach, backshore) at that location. \\
\hline Habitat availability & Raster layer, continuous & $\begin{array}{l}\text { Probability that given location is piping plover habitat. This is an output vari- } \\
\text { able only and is not associated with an input dataset. }\end{array}$ \\
\hline Substrate type (SubType) & Raster layer, categorical & Substrate type at that location. \\
\hline Vegetation density (VegDen) & Raster layer, categorical & Vegetation density at that location. \\
\hline Vegetation type (VegType) & Raster layer, categorical & Vegetation type at that location. \\
\hline
\end{tabular}

${ }^{1}$ Definitions of categorical variables are given in table 4. 


\section{Initial Data Sources}

In this section, we describe the initial data sources used to derive biogeomorphic metrics and geospatial datasets for the BNs. These products are summarized by study area and year in table 2 and by study area in table 3 .

\section{Lidar}

We obtained digital elevation models (DEMs) derived from high-resolution light detection and ranging (lidar) returns for each year of analysis and each study area (table 2). Whenever possible, the same source lidar dataset was used to extract the shoreline and foredune positions. The DEMs were used (1) to delineate the ocean-side and bay-side shorelines of the barrier island, (2) to obtain elevations and calculate slope at 5-m spacing along the transects, (3) to measure beach height along transects without an associated foredune toe, (4) to compute elevation adjusted to the local mean high water (MHW) datum for the entire barrier island, and (5) as a reference during error-checking routines.

\section{Orthoimagery}

We obtained high-resolution $(\leq 1 \mathrm{~m})$ orthoimagery for dates that most closely coincided with the lidar survey for each study area and time period of analysis (table 2). These data were used for land cover classification (for example, maps of vegetation type, vegetation density, and substrate type), manual digitization of armoring and geomorphic settings, and reference during error checking.

\section{National Assessment of Shoreline Change Transects}

Barrier island metrics used in this study were sampled at 5-m intervals along shore-normal transects spaced $50 \mathrm{~m}$ apart. These transects were originally delineated as part of the U.S. Geological Survey (USGS) National Assessment of Shoreline Change (NASC) (Himmelstoss and others, 2010; Hapke and others, 2011). NASC transects are associated with shoreline change rates calculated by Hapke and others (2011). The transect geometries were modified and supplemented for this project, as described in more detail in a subsequent section (see "Supplemented Transects" in the "Intermediate Datasets" section of this report).

\section{Mean High Water Offsets}

Elevation-based metrics were originally referenced to North American Vertical Datum of 1988 (NAVD 88), but for the purposes of these analyses (table 3), elevations were adjusted to local MHW by using corrections from Weber and others (2005). These adjustments predate the availability of the National Oceanic and Atmospheric Administration (NOAA; 2018) VDatum datasets and are the standard used to adjust USGS coastal lidar datasets (Doran and others, 2017).

\section{Shoreline and Foredune Positions}

Doran and others (2017) calculated shoreline positions, beach slopes, foredune crest positions, and foredune toe positions from lidar point clouds for storm effect assessments conducted by the USGS (Plant and Stockdon, 2012; Stockdon and others, 2012; Doran and others, 2017). In the Doran and others (2017) routine, features are extracted from lidar swaths along shore-normal transects delineated from a local baseline at regular alongshore spacing (usually $10 \mathrm{~m}$ ). The shoreline is recorded as the horizontal position of the MHW elevation in latitude and longitude. The foredune crest is identified as the highest elevation nearest the sea (Stockdon and others, 2009; Doran and others, 2017). The foredune toe is the point of greatest inflection between the shoreline and the foredune crest (Doran and others, 2017). The foredune toe and crest positions were recorded as latitude, longitude, and elevation, with elevations referenced to NAVD 88 and adjusted to the local MHW datum (Weber and others, 2005). These data were used to derive a number of metrics and raster layers used in this study, including beach width, beach height, foredune height, and geomorphic setting.

When possible, published shoreline and foredune positions were used. However, when these data were not available, we extracted shoreline and foredune positions on the basis of the methods of Doran and others (2017) and Stockdon and others $(2009,2012)$. Positions that were extracted as part of this study and not published previously are distributed in an associated USGS data release (Sturdivant and others, 2019).

\section{Methods-Barrier Island Geomorphology Bayesian Network}

In this section, we describe the methods used to produce intermediate and $\mathrm{BN}$ datasets associated with the Barrier Island Geomorphology BN developed initially by Gutierrez and others (2015). Variables relevant for the Barrier Island Geomorphology BN characterize either transect averages or conditions at point locations. Transect-averaged metrics are characteristics of the barrier island cross section, whereas point metrics reflect variables that were extracted every $5 \mathrm{~m}$ along each cross-shore transect (figs. 4 and 5). The 5-m scale was deemed relevant for piping plover nesting habitat in Gieder and others (2014), and therefore we retained this scale for both BNs.

Processing relied on Esri ArcMap (version 10.5) and the Python programming language environment distributed with ArcGIS Pro (version 2.0) unless otherwise noted. Processing 
Table 2. Initial data sources by study area and year used to derive inputs to the Barrier Island Geomorphology and Piping Plover Habitat Bayesian networks.

[m, meter; NWR, National Wildlife Refuge; NS, National Seashore; USGS, U.S. Geological Survey; CMGP, Coastal and Marine Geology Program; NAVD 88, North American Vertical Datum of 1988; NOAA, National Oceanic and Atmospheric Administration; lidar, light detection and ranging; DEM, digital elevation model; EAARL-B, Experimental Advanced Airborne Research Lidar; USACE, U.S. Army Corps of Engineers; VITA, Virginia Information Technologies Agency; VGIN, Virginia Geographic Information Network; JALBTXC, Joint Airborne Lidar Bathymetry Technical Center of eXpertise; NCMP, National Coastal Mapping Program; USDA, U.S. Department of Agriculture; NAIP, National Agricultural Inventory Program; NGS, National Geodetic Survey; DMC, Digital Media Camera]

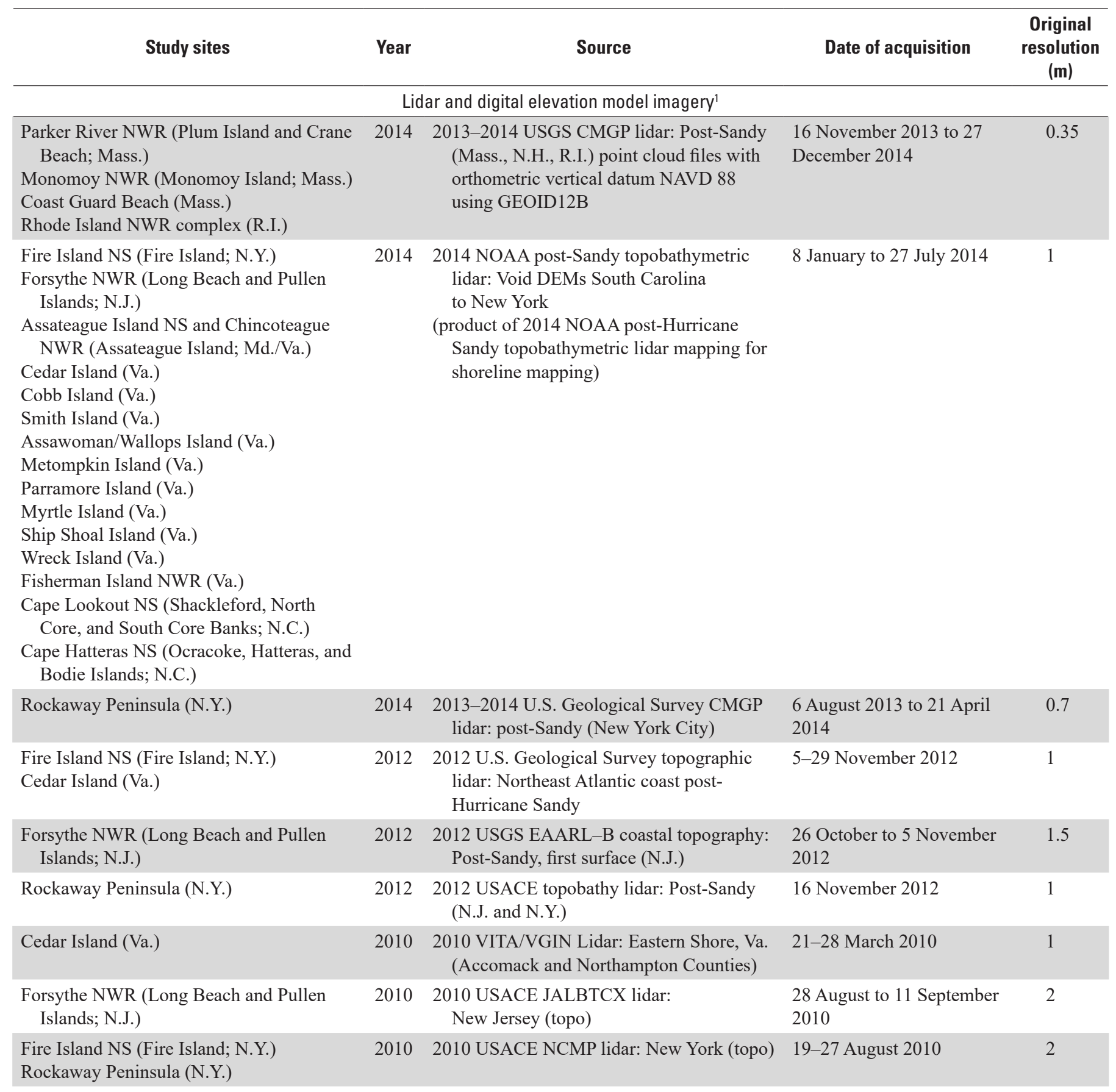


Table 2. Initial data sources by study area and year used to derive inputs to the Barrier Island Geomorphology and Piping Plover Habitat Bayesian networks.-Continued

[m, meter; NWR, National Wildlife Refuge; NS, National Seashore; USGS, U.S. Geological Survey; CMGP, Coastal and Marine Geology Program; NAVD 88, North American Vertical Datum of 1988; NOAA, National Oceanic and Atmospheric Administration; lidar, light detection and ranging; DEM, digital elevation model; EAARL-B, Experimental Advanced Airborne Research Lidar; USACE, U.S. Army Corps of Engineers; VITA, Virginia Information Technologies Agency; VGIN, Virginia Geographic Information Network; JALBTXC, Joint Airborne Lidar Bathymetry Technical Center of eXpertise; NCMP, National Coastal Mapping Program; USDA, U.S. Department of Agriculture; NAIP, National Agricultural Inventory Program; NGS, National Geodetic Survey; DMC, Digital Media Camera]

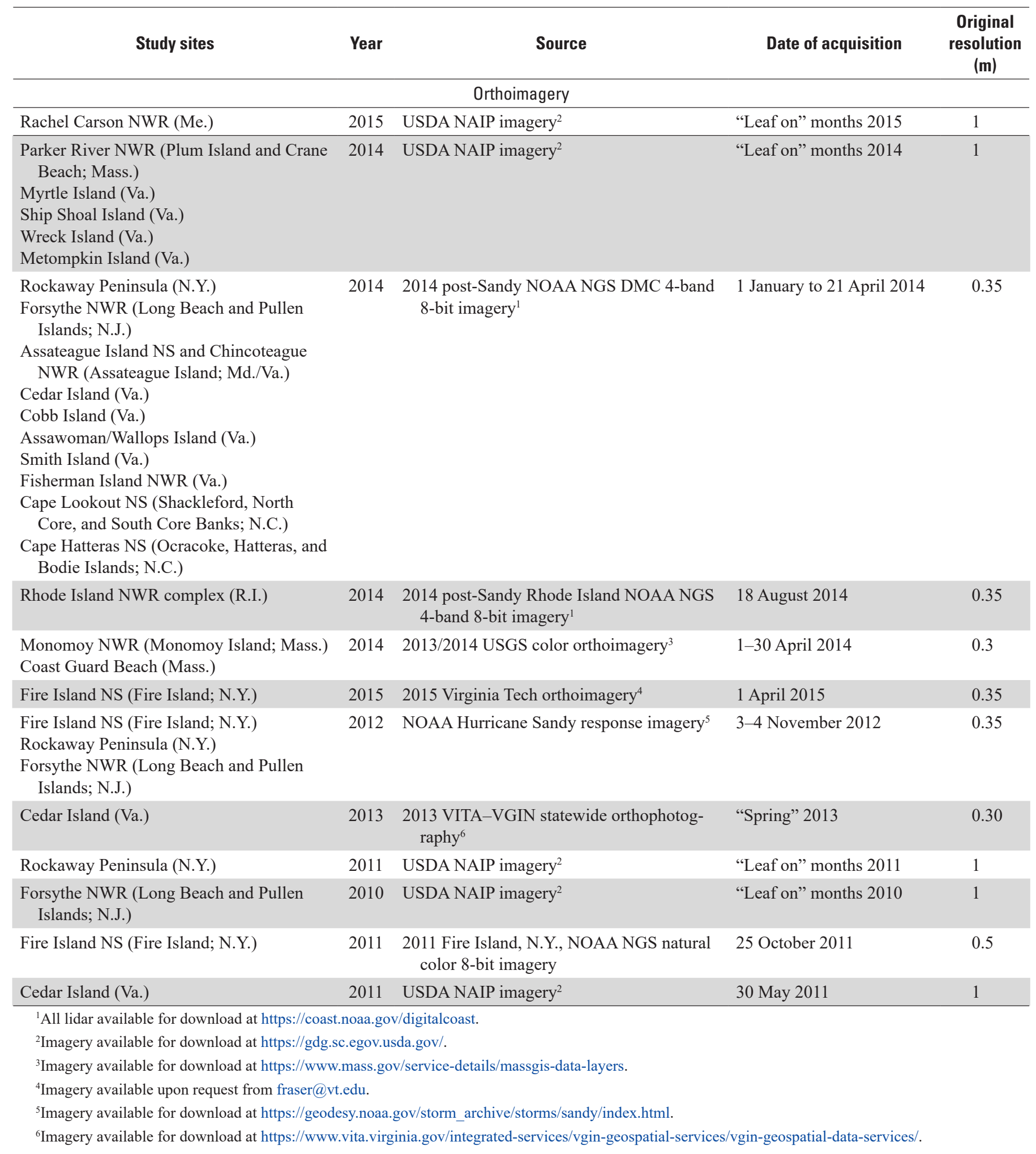


Table 3. Mean high water corrections and Universal Transverse Mercator zone, by study area, used to derive inputs to the Barrier Island Geomorphology and Piping Plover Habitat Bayesian networks.

[NAVD 88, North American Vertical Datum of 1988; MHW, mean high water; UTM; Universal Transverse Mercator; NAD 83, North American Datum of 1983; NWR, National Wildlife Refuge; NS, National Seashore]

\begin{tabular}{|c|c|c|}
\hline Study area & $\begin{array}{c}\text { Correction } \\
\text { height in } \mathrm{m} \text { for } \\
\text { adjustment from } \\
\text { NAVD } 88 \text { to } \\
\text { MHW }^{1}\end{array}$ & $\begin{array}{l}\text { UTM Zone } \\
\text { (NAD 83) }\end{array}$ \\
\hline Rachel Carson NWR (Me.) & 1.22 & 19 \\
\hline $\begin{array}{l}\text { Parker River NWR (Plum Island } \\
\text { and Crane Beach; Mass.) }\end{array}$ & 1.22 & 19 \\
\hline Coast Guard Beach (Mass.) & 0.98 & 19 \\
\hline Monomoy NWR (Mass.) & 0.39 & 19 \\
\hline $\begin{array}{l}\text { Rhode Island NWR complex } \\
\text { (R.I.) }\end{array}$ & 0.36 & 19 \\
\hline Fire Island NS (N.Y.) & 0.46 & 18 \\
\hline Rockaway Peninsula (N.Y.) & 0.46 & 18 \\
\hline $\begin{array}{l}\text { Forsythe NWR (Long Beach and } \\
\text { Pullen Islands; N.J.) }\end{array}$ & 0.43 & 18 \\
\hline $\begin{array}{l}\text { Assateague Island NS and Chin- } \\
\text { coteague NWR (Assateague } \\
\text { Island; Md./Va.) }\end{array}$ & 0.34 & 18 \\
\hline Cedar Island (Va.) & 0.34 & 18 \\
\hline Cobb Island (Va.) & 0.34 & 18 \\
\hline Assawoman/Wallops Island (Va.) & 0.34 & 18 \\
\hline Smith Island (Va.) & 0.34 & 18 \\
\hline Metompkin Island (Mass.) & 0.34 & 18 \\
\hline Myrtle Island (Va.) & 0.34 & 18 \\
\hline Ship Shoal Island (Va.) & 0.34 & 18 \\
\hline Wreck Island (Va.) & 0.34 & 18 \\
\hline Parramore Island (Va.) & 0.34 & 18 \\
\hline Fisherman Island NWR (Va.) & 0.34 & 18 \\
\hline $\begin{array}{l}\text { Cape Lookout NS (Shackleford, } \\
\text { North Core, and South Core } \\
\text { Banks; N.C.) }\end{array}$ & 0.36 & 18 \\
\hline $\begin{array}{c}\text { Cape Hatteras NS (Ocracoke, Hat- } \\
\text { teras, and Bodie Islands; N.C.) }\end{array}$ & 0.26 & 18 \\
\hline
\end{tabular}

${ }^{1}$ Mean high water correction factor are from Weber and others (2005). was automated in a Python package and accompanying Jupyter notebooks. The package is available in the USGS code repository (Sturdivant, 2019), and the Jupyter notebook used to create each dataset is provided with the published dataset. Published datasets are released separately in Sturdivant and others (2019). These published datasets include variables that were used to calculate the final $\mathrm{BN}$ datasets, which we refer to as processing variables. We describe the methods for deriving the processing variables together with those for deriving the $\mathrm{BN}$ datasets, which we distinguish by showing their abbreviations in bold font.

\section{Intermediate Datasets}

\section{Supplemented Transects}

NASC transects from Himmelstoss and others (2010) were modified for the purposes of this study. Transects were extended inland to cover the width of the island, and additional transects were added to fill alongshore gaps greater than $50 \mathrm{~m}$. Transects were extended by using the last two vertices of each transect to programmatically place the end of the line $3,000 \mathrm{~m}$ beyond the end of the original line segment. Transects were assigned identification (ID) values that ordered transects consecutively along the shoreline. Transects that were manually added did not include shoreline change rates and were instead populated with fill values. We eliminated transect overlap in some locations by manually clipping the transects to the first intersection point with an overlapping transect. While doing so, we prioritized the original NASC transect geometries. Nonoverlapping supplemented transects retained the azimuths and starting points of the original lines but in some cases were shortened.

\section{Transect Points}

A point dataset was created from the nonoverlapping supplemented transects file. Points were created by (1) clipping the transects to the terrestrial part of the study area by using the full island shoreline (see next subsection), (2) splitting the clipped transects into 5-m segments, and (3) assigning the centers of the segments as the point locations. Points were sorted and assigned ID values (SplitSort) that ordered them by transect and by cross-shore distance from the ocean.

\section{Full Island Shoreline}

A polygon outlining the shoreline of the island was created for each study area. On the ocean-facing side of the island, this was considered the MHW contour. On the 


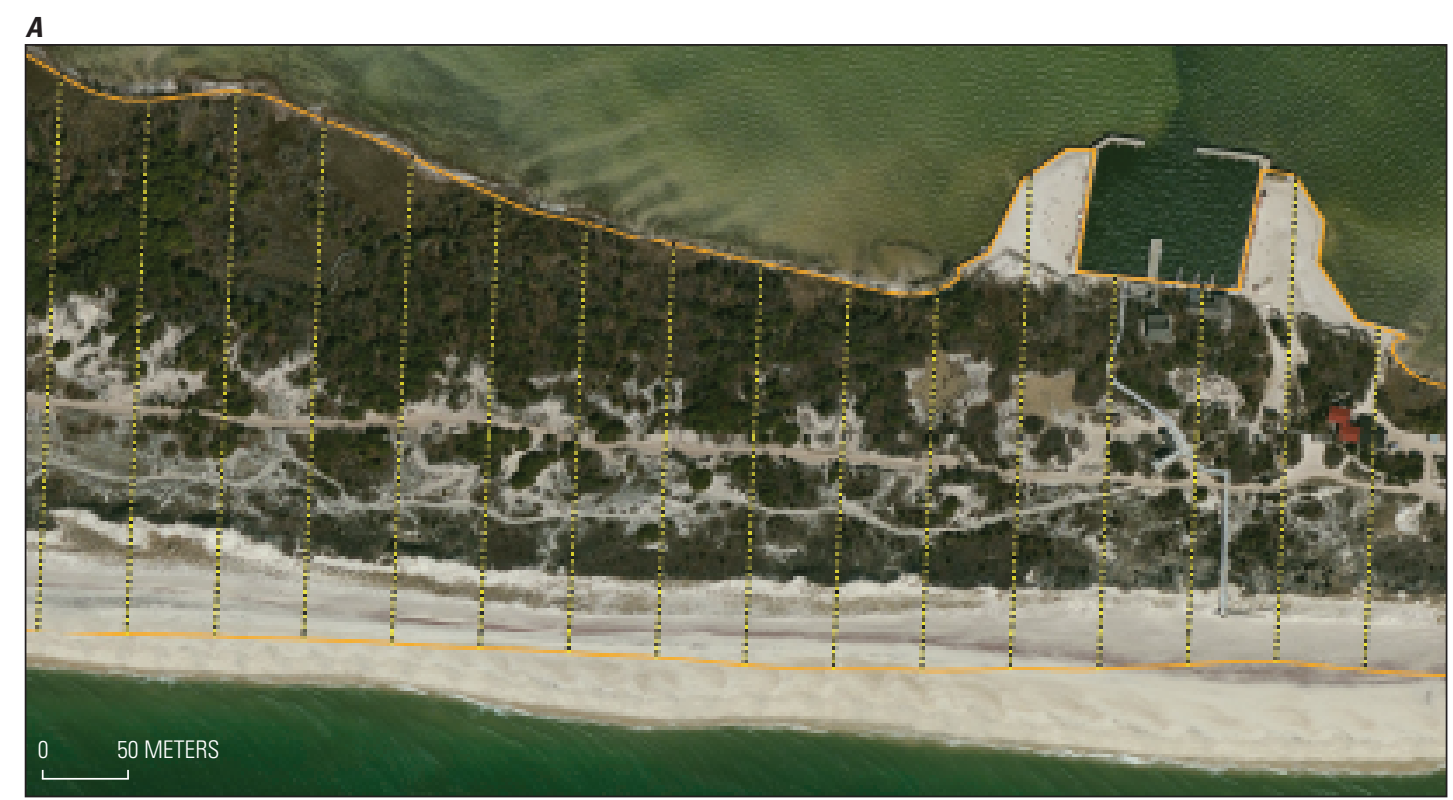

B

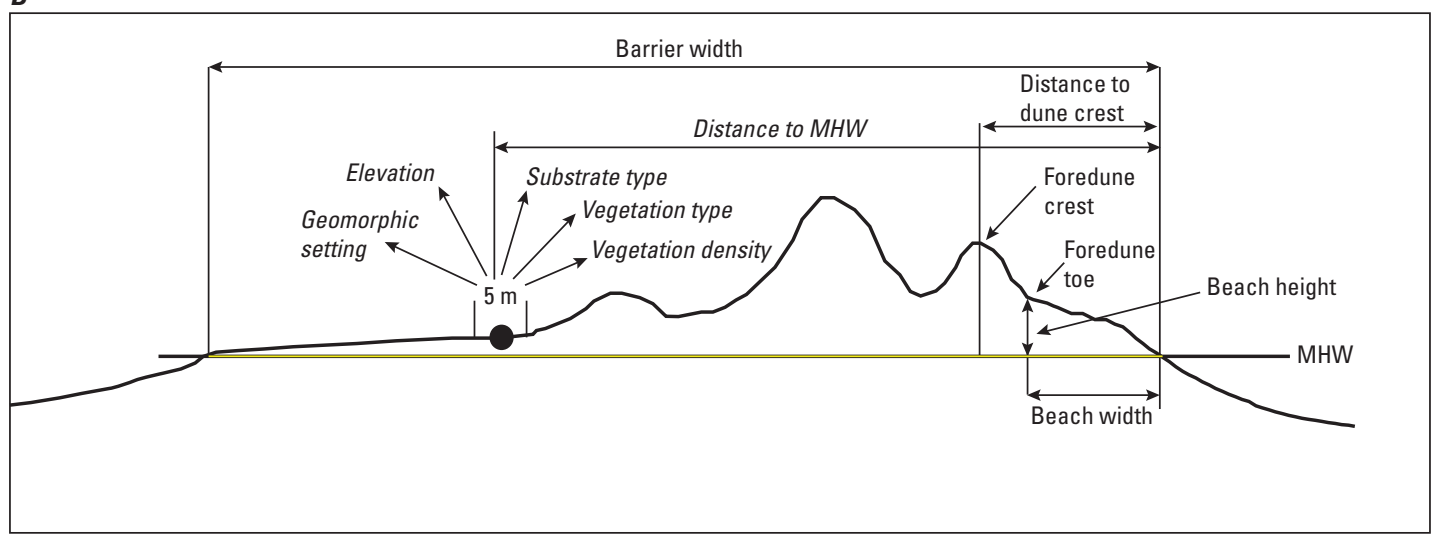

Figure 5. Diagram of barrier island metrics. $A$, Aerial orthoimage of Fire Island, New York showing an example of the transect-based and point-based data sampling scheme used to derive barrier island metrics. Yellow lines indicate the transects along which transect-averaged barrier island metrics were calculated. Black dots indicate the center points, spaced in 5-meter $(\mathrm{m})$ intervals, at which barrier island metrics were derived. Orange lines indicate bay-side and ocean-side shorelines. $B$, Schematic of a cross-section view of a single transect and specific metrics that were used to characterize both cross-island morphology (mean high water position [MHW], barrier width, beach height, beach width, distance to foredune crest, foredune crest, foredune toe) and finer scale (5-m points) barrier island metrics (italicized; elevation, substrate type, geomorphic setting, vegetation type, vegetation density, distance to MHW). 
bay-side, the shoreline was delineated at mean tidal level (MTL), which was calculated from the local MHW and mean low water (MLW) levels at the given study area. The local MLW elevation was estimated from NOAA's VDatum as the average MLW elevation at a sample of nearshore points in the study area. Experimentation conducted as part of this study found that the MTL delineation more consistently identified the boundary between marsh (intertidal vegetation) and submerged areas than either MHW or MLW. For consistency with the MHW correction applied throughout the project, MHW was used as part of the calculation of MTL.

To create this shoreline, we performed the following steps:

1. Manually digitize a line from the DEM that indicates where land meets a tidal inlet, which is also considered the division point between the ocean-side and the bayside of the island. This line was visually approximated.

2. Create a polygon from the DEM in which every cell within the polygon is above MHW.

3. Repeat step 2 for MTL.

4. Merge the polygons so that the MHW contour outlines the island on the ocean-side and the MTL contour outlines the island on the bay-side. The division between ocean-side and bay-side is at the delineated tidal inlets. To do so, divide the outlines at the tidal inlets and combine the MTL line from the bay-side with the MHW line from the ocean-side.

5. Adjust the ocean-side line to precisely match the MHW shoreline positions (Doran and others, 2017). Snap the polygon to the shoreline points where it is within $25 \mathrm{~m}$ of a point.

\section{Bayesian Network Datasets: Transect-Averaged Metrics}

\section{Transect Identifiers}

Two types of transect identifiers were included for the transect-averaged metrics, which can be used for ordering transects along the coast and for spatially joining metric values to transect lines in ArcMap:

1. NASC transect identifier (TID): a numerical identifier from the NASC transect source data (Himmelstoss and others, 2010). A fill value of -99999 indicates a new transect that was added to fill alongshore gaps in the NASC transects.

2. Barrier island transect identifier (DD_ID): numerical identifier of the data sampling transect at a particular study site. These values are unique across all sites. They can be used to sort transects alongshore within a given study site.

\section{Shoreline Change Rates}

Long-term shoreline change rates (LRR), representing change during approximately the past 150 years, were obtained from the NASC (Himmelstoss and others, 2010; Hapke and others, 2011). These are linear regression rates of long-term shoreline change calculated from a set of 6 to 10 historical shorelines spanning the time period between 1845 and 2000 (Himmelstoss and others, 2010). Although these rates were not established as part of this study, they act as an input variable in the Barrier Island Geomorphology BN, and each transect contained in associated data releases is populated with a shoreline change rate.

\section{Beach Width and Height}

Here and throughout this report, "upper beach" is synonymous with "backshore" and describes the upper, usually dry, zone of the coastline that lies between the MHW shoreline and either (1) the foredune toe, (2) the edge of developed areas occupying land adjacent to the beach, or (3) the edge of dense vegetation (or forest). The upper beach width (uBW) and upper beach height ( $\mathbf{u B H})$ measure the horizontal and vertical distances, respectively, between the MHW shoreline and the foredune toe. The positions of the MHW shoreline and the foredune toe or equivalent were resampled to the NASC transects as described in the following subsections.

\section{Mean High Water Position and Foreshore Slope Along Transect}

The position of the MHW shoreline along each transect is presented in easting and northing and was calculated as the intersection of the transect with the MHW shoreline. Each transect is assigned foreshore slope from the nearest shoreline morphology point within $25 \mathrm{~m}$.

\section{Foredune Positions and Elevations Along Transects}

The positions and elevations of the nearest foredune toe and foredune crest (in X, Y, and Z) within $25 \mathrm{~m}$ of each transect are used to measure the beach geomorphology along the transect. These positions were derived directly from foredune positions published in Doran and others (2017). We performed two additional conversions: (1) we adjusted the elevation from NAVD 88 to elevation above local MHW (Weber and others, 2005), and (2) we calculated the orthogonal position of the foredune point along the transect. In cases where foredune toe extraction was confounded by the presence of an artificial structure, the position of the first artificial structure in the vicinity of the beach (Arm_x, Arm_y, Arm_z) was used to supplement the foredune toe dataset by providing an upper limit to the beach. These positions are the intersection points of each transect with the armoring lines, which are line segments manually digitized immediately seaward of artificial 
impediments to sediment transport (for example, sand-fencing, sandbags, or seawalls).

Because foredune toe was not always the most appropriate inland-most boundary of the beach, beach width and height were calculated from either the position of the foredune toe, the foredune crest, or the base of an armoring structure. The foredune crest was only used at the inland-most beach boundary when the dune crest elevation was less than or equal to $2.5 \mathrm{~m}$ (except for the Monomoy National Wildlife Refuge, where the threshold value was $3 \mathrm{~m}$ ). Upper beach width and height were calculated primarily by using the snapToLine geometry method in ArcPy and Pandas for data storage and organization.

\section{Distance to Inlet}

Distance to inlet (Dist2Inlet) is computed as the alongshore distance between each sampling transect and the nearest tidal inlet. Rather than the Euclidean distance between each transect and the inlet, this distance includes changes in the path of the shoreline and thus better reflects alongshore sediment transport pathways compared to Euclidean distance. It was measured by using the full shoreline polygon and tidal inlet locations, which were created for the production of the full island shoreline (see "Full Island Shoreline" section of this report). We first created a polyline feature class representing only the seaward shoreline and then measured the distance along that shoreline to the transect in the following steps:

1. Split the full island shoreline at the tidal inlets by converting the shoreline polygon into a polyline feature class with the inlet lines included.

2. Retain only the ocean-side segments of the shoreline by deleting all segments that do not intersect any MHW shoreline points.

3. If inlets bound both sides of the MHW shoreline, measure the distance to each inlet and assign the minimum distance of the two. If the MHW shoreline meets only one inlet (meaning the study area ends before the island ends), use the distance to the only inlet.

\section{Cross-Island Width}

Along-transect (cross-island) width of the barrier island (WidthLand) was calculated as the above-water distance between the back-barrier (or bay-side) and ocean-side MHW shorelines. Cross-island width only includes regions of the barrier within the shoreline delineated by the full island shoreline and did not extend into any of the sinuous or intervening back-barrier waterways and islands. Full island width, which includes the space occupied by waterways, was also recorded and specifies the width of only the most seaward portion of land within the shoreline.

\section{Mean Transect Elevation}

We calculated the mean (Mean_zMHW) and maximum barrier elevations from the elevation values measured at points spaced in 5-m intervals along each transect (see subsection "Elevation and Slope" in the "Bayesian Network Datasets: 5-Meter Point Metrics" section of this report). Mean barrier elevations were calculated for only those transects where less than 20 percent of the points along that transect were missing elevation values. Locations not satisfying this criterion were assigned a fill value (-99999).

\section{Anthropogenic Modifications}

We included three fields detailing anthropogenic modifications to the barrier island: nourishment, construction, and development. Categorical dummy values were assigned to each transect manually through visual inspection of available aerial orthoimagery and the DEM and by consulting other external sources, most often a report and accompanying geospatial data by Rice $(2015 \mathrm{a}, \mathrm{b})$ (table 4$)$. Values were determined on the basis of the following criteria:

1. Nourishment: A numerical code specifying if there was (a) no record of beach nourishment at a site (value=111), (b) occasional beach nourishment (has occurred at least once in recent decades; value $=222$ ), or (c) frequent beach nourishment $(\leq 1-2$-year frequency; value $=333)$. Reports by Rice $(2015 \mathrm{a}, \mathrm{b})$ were consulted to determine nourishment histories for each site.

2. Construction: A numerical code specifying if there were (a) no constructed features (value=111), (b) soft shoreline stabilization strategies (for example, constructed dunes or berms, sand fencing, geotubes; value $=222$ ), (c) hard structures (for example, rip-rap, seawalls, groins, jetties; value $=333$ ), or (d) both soft and hard strategies (value $=444$ ).

3. Development: A numerical code specifying the level of development present along a transect. Examples of each definition are provided in figure 6. The level of development could include (a) none, where no development was present (value $=111$; fig. $6 A$ ); (b) light, which includes the presence of a road, paved or unpaved, and the occasional structure (for example, a house; value $=222$; fig. $6 B$ ); (c) moderate, which includes the presence of more extensive roads and (or) buildings along a transect (value=333; fig. 6C); or (d) heavy, which indicates a high density of paved surfaces, houses, or buildings along a transect (value $=444$; fig. $6 D$ ). 
Table 4. Definitions of categorical variables used to describe land cover characteristics associated with piping plover habitat and nonhabitat in the Barrier Island Geomorphology and Piping Plover Habitat Bayesian networks.

[MHW, mean high water; mm, millimeter; m, meter; <, less than; >, greater than; \%, percent]

\begin{tabular}{|c|c|}
\hline Variable & Definition \\
\hline \multicolumn{2}{|r|}{ Geomorphic setting } \\
\hline Beach & $\begin{array}{l}\text { The relatively thick and temporary accumulation of loose, water-borne material (usually well-sorted sand and pebbles, } \\
\text { accompanied by mud, cobbles, boulders, and smoothed rock and shell fragments) that is in active transit along, or de- } \\
\text { posited on, the shore zone between the limits of low water and high water (Neuendorf and others, 2011). In this study, } \\
\text { all area below the MHW shoreline and not designated as marsh is included in the beach geomorphic setting. }\end{array}$ \\
\hline $\begin{array}{l}\text { Backshore (also } \\
\text { referred to as } \\
\text { upper beach) }\end{array}$ & $\begin{array}{l}\text { The upper, usually dry, zone of the shore or beach, lying between the high-water line of mean spring tides and the upper } \\
\text { limit of shore-zone processes; it is acted upon by waves or covered by water only during severe storms or unusually } \\
\text { high tides (Johnson, 1919; Davis, 1985; Neuendorf and others, 2011). In this study, the backshore geomorphic setting } \\
\text { was defined as the region between the MHW shoreline and either (1) the foredune toe, (2) the edge of developed } \\
\text { areas occupying land adjacent to the beach, or (3) the edge of dense vegetation (or forest). }\end{array}$ \\
\hline Dune complex & $\begin{array}{l}\text { A mound, ridge, bank, or hill of loose, windblown granular material (generally sand), either bare or covered by vegeta- } \\
\text { tion, capable of movement from place to place but retaining its characteristic shape (Neuendorf and others, 2011). In } \\
\text { this study, dune also describes low-lying areas between dunes (or interdune regions) that are part of the larger dune } \\
\text { complex. }\end{array}$ \\
\hline Washover & $\begin{array}{l}\text { A fan of material deposited from the ocean landward on a mainland beach or barrier island, produced by storm waves } \\
\text { breaking over low parts of the mainland beach or barrier and depositing sediment either landward (mainland beaches) } \\
\text { or across a barrier island into the bay or sound (barrier islands). A washover typically displays a characteristic fanlike } \\
\text { shape (Leatherman and others, 1977; Neuendorf and others, 2011). }\end{array}$ \\
\hline Barrier interior & $\begin{array}{l}\text { In this study, the barrier interior geomorphic setting described all areas spanning the interior boundary of the dunes (or } \\
\text { backshore in the absence of dunes) on the ocean-side to the interior boundary of the marsh, dunes, or backshore on } \\
\text { the back-barrier side. This setting was typically used to describe areas that did not fall into any other geomorphic set- } \\
\text { ting (for example, washovers, ridge or swale complexes). }\end{array}$ \\
\hline $\begin{array}{l}\text { Ridge-swale } \\
\text { complex }\end{array}$ & $\begin{array}{l}\text { Long subparallel ridges and swales aligned obliquely across the regional trend of the contours. Common on the hooks } \\
\text { (that is, a low peninsula or barrier ending in a recurved spit and formed at the end of a bay, like the hook of } \\
\text { Assateague Island) of barrier islands of the mid-Atlantic United States (Neuendorf and others, 2011). }\end{array}$ \\
\hline Marsh & $\begin{array}{l}\text { A relatively flat, low-lying, intermittently water-covered area with generally halophytic grasses typically existing on the } \\
\text { landward side of a barrier island (Neuendorf and others, 2011). }\end{array}$ \\
\hline \multicolumn{2}{|r|}{ Substrate type } \\
\hline Sand & $\begin{array}{l}\text { Rock or mineral grains with diameters between } 0.074 \text { and } 4.76 \mathrm{~mm} \text { (Neuendorf and others, 2011). In this study, a pre- } \\
\text { dominantly sand substrate consisted of finer grains with no discernible shells fragments or large rock fragments. }\end{array}$ \\
\hline Shell/gravel/cobble & In this study, shell/gravel/cobble described substrate containing a mixture of sand, shell or rock fragments, or large rocks. \\
\hline Mud/peat & A sticky, fine-grained, predominantly clay- or silt-sized marine detrital sediment (Neuendorf and others, 2011). \\
\hline Water & $\begin{array}{l}\text { In this study, we selected water as the substrate type for any area that (1) is always submerged (for example, areas } \\
\text { several meters into the ocean, bay, or inland water body), (2) was submerged at the time orthoimagery was captured } \\
\text { (for example, intertidal regions of beaches), or (3) was seaward of the mean high water shoreline. }\end{array}$ \\
\hline Development & $\begin{array}{l}\text { In this study, we selected development as the substrate type for any areas that were obviously influenced by anthropo- } \\
\text { genic activities (for example, housing developments, paved roads or parking lots, recreational sports fields). }\end{array}$ \\
\hline
\end{tabular}

Vegetation type
None
Areas lacking vegetation of any type. Such areas were common on beaches, backshores, and washovers that frequently or recently experienced wave-action.
Herbaceous
Areas containing primarily herbaceous vegetation of the forb-herb growth habit (U.S. Department of Agriculture, 2015) and lacking shrubs, trees, or any other vegetation with woody stems (Neuendorf and others, 2011). In this study, the herbaceous vegetation type typically described the vegetation cover found in Godfrey (1976) grassland ecological zone along the backshore and dunes, dominated by beach grasses (for example, Ammophila breviligulata) or intertidal marsh ecological zone dominated by cordgrass (for example, Spartina patens).

Shrub

Areas containing low $(<5 \mathrm{~m})$, multistemmed woody plants of the subshrub or shrub growth habits (U.S. Department of Agriculture, 2015). In this study, the shrub vegetation type typically described vegetation cover found in Godfrey (1976) heath-like shrublands ecological zone in stable dune systems. 
Table 4. Definitions of categorical variables used to describe land cover characteristics associated with piping plover habitat and nonhabitat in the Barrier Island Geomorphology and Piping Plover Habitat Bayesian networks._-Continued

[MHW, mean high water; mm, millimeter; m, meter; <, less than; >, greater than; \%, percent]

\begin{tabular}{|c|c|}
\hline Variable & Definition \\
\hline \multicolumn{2}{|r|}{ Vegetation type-Continued } \\
\hline Forest & $\begin{array}{l}\text { Areas containing trees and tall }(>5 \mathrm{~m} \text { ) shrubs of the tree growth habit (U.S. Department of Agriculture, 2015). In this } \\
\text { study, the forest vegetation type typically described vegetation cover found in Godfrey (1976) woodlands-forests eco- } \\
\text { logical zone found in barrier island interiors and dominated by deciduous (for example, Quercus velutina), pine (for } \\
\text { example, Pinus rigida), and juniper (for example, Juniperus virginiana) species. }\end{array}$ \\
\hline Development & $\begin{array}{l}\text { In this study, we selected development as the vegetation type for any areas that were obviously influenced by anthropo- } \\
\text { genic activities (for example, housing developments, paved roads or parking lots, recreational sports fields). }\end{array}$ \\
\hline \multicolumn{2}{|r|}{ Vegetation density } \\
\hline None & No vegetation observed in the $5-\times 5-\mathrm{m}$ map cell. \\
\hline Sparse & Vegetation was apparent and covered approximately $<20 \%$ of the $5-\times 5$-m map cell. \\
\hline Moderate & Vegetation covered approximately 20 to $90 \%$ of the $5-\times 5-\mathrm{m}$ map cell. \\
\hline Dense & Vegetation covered approximately $>90 \%$ of the $5-\times 5-\mathrm{m}$ map cell. \\
\hline Development & $\begin{array}{l}\text { In this study, we selected development as the vegetation density for any areas that were obviously influenced by anthro- } \\
\text { pogenic activities (for example, housing developments, paved roads or parking lots, recreational sports fields). }\end{array}$ \\
\hline \multicolumn{2}{|r|}{ Anthropogenic modification—Nourishment (dummy variable) } \\
\hline None (111) & Nourishment was not conducted at that location in recent history. \\
\hline Occasional (222) & Nourishment has occurred at least once in recent decades. \\
\hline Frequent (333) & Nourishment over periods of $1-2$ years or less (for example, nourishment occurs twice every year). \\
\hline \multicolumn{2}{|r|}{ Anthropogenic modification-Construction (dummy variable) } \\
\hline No features (111) & No erosion control measures are present. \\
\hline Soft (222) & Soft erosion control measures (for example, constructed dunes or berms) are present. \\
\hline Hard (333) & Hard erosion control measures (for example, seawalls, groins, jetties) are present. \\
\hline Hard and soft (444) & Both hard and soft erosion control measures are present. \\
\hline \multicolumn{2}{|r|}{ Anthropogenic modification-Development (dummy variable) } \\
\hline None (111) & No human development is present (fig. 6A). \\
\hline Light (222) & Limited human development is present (for example, a paved or unpaved road, an occasional house; fig. $6 B$ ). \\
\hline Moderate (333) & More extensive human development is present (for example, paved roads, houses; fig. 6C). \\
\hline Heavy (444) & A high density of buildings, roads, and paved surfaces are present (fig. $6 D$ ). \\
\hline
\end{tabular}




\section{A. None}

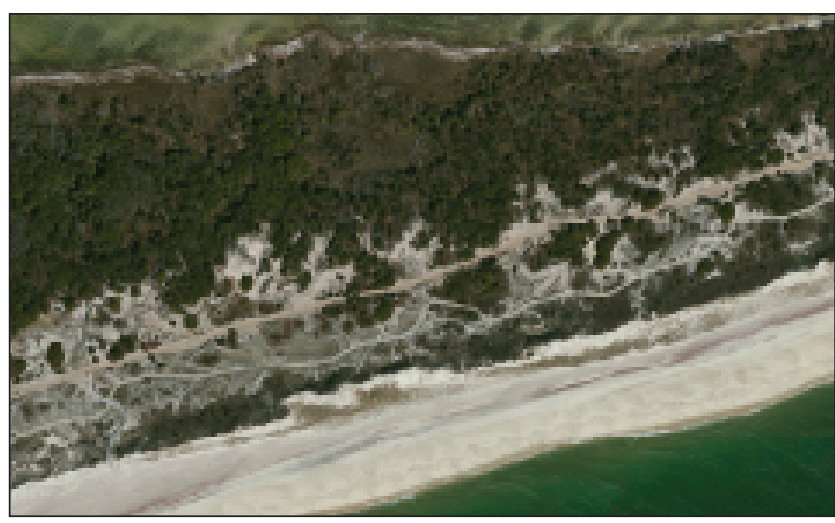

\section{Moderate}

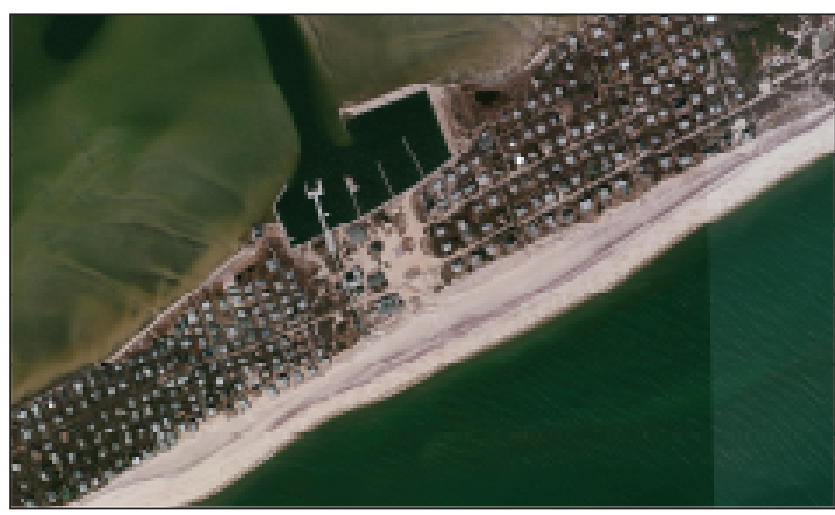

B. Light

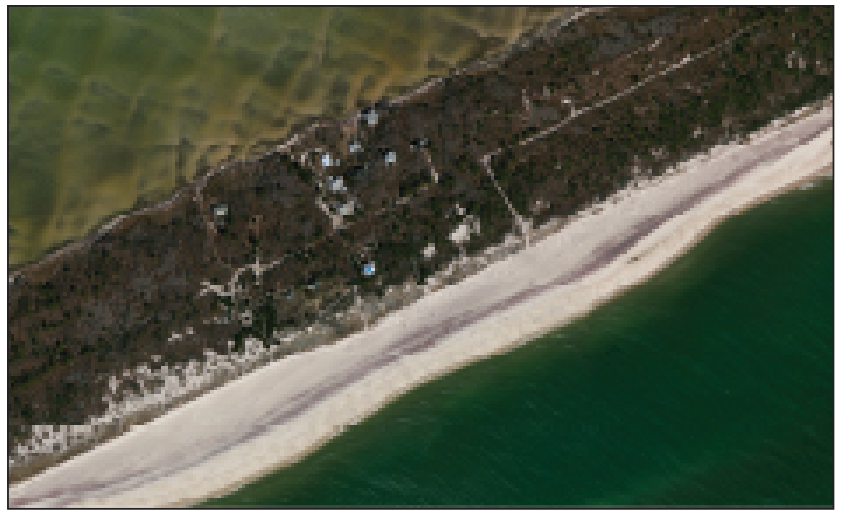

\section{Heavy}

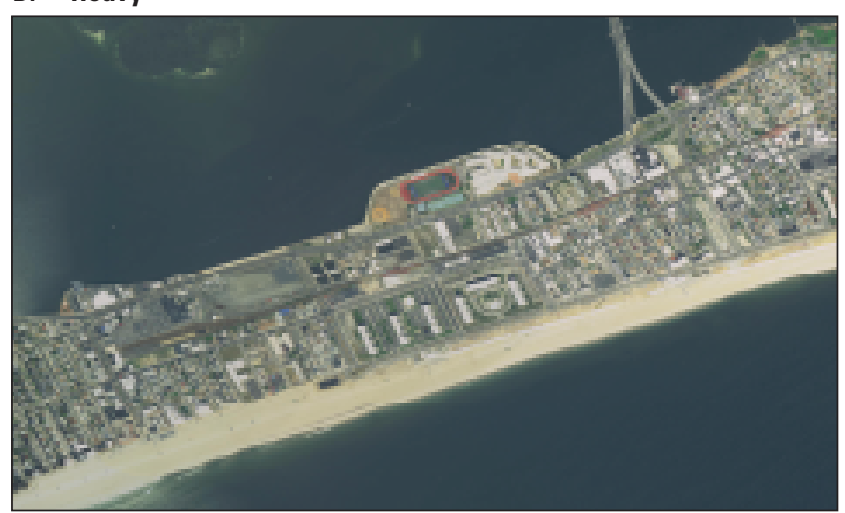

Figure 6. Aerial orthoimagery illustrating the four categories of anthropogenic development considered in this study: $A$, none, $B$, light, $C$, moderate, and $D$, heavy. Example orthoimagery shown here depicts Fire Island $(A, B$, and $C)$ and the Rockaway Peninsula $(D)$ in New York.

\section{Bayesian Network Datasets: 5-Meter Point Metrics}

\section{Distances}

Distance to the ocean shoreline (Dist_Seg) and to the dune crest (DistDH) was calculated as the Euclidean distance from the 5-m transect point to the MHW ocean-side shoreline and to the foredune crest, respectively. Euclidean distance from each 5-m point to the bay shoreline (Dist_MHWbay), foredune toe, and shoreline armoring were also recorded for each transect and are included site-specifically in Sturdivant and others (2019).

\section{Elevation}

Elevation (ptZmhw) and slope values were also associated with each 5-m transect point by using the Extract Multi Values to Points tool. These values were calculated from the
DEM surface (resampled to a 5- $\times 5-\mathrm{m}$ resolution and corrected for MHW datum) in ArcMap.

\section{Habitat Variables}

Finally, we assigned coded values for four land cover variables associated with piping plover habitats to each 5-m point along each transect. These variables are (1) vegetation type (VegType), (2) vegetation density (VegDens), (3) geomorphic setting (GeoSet), and (4) substrate type (SubType). We also included a variable for the least cost path distance to foraging areas for piping plovers for each 5-m transect point (DisMOSH); however, this variable is not currently included in the Barrier Island Geomorphology BN. Values for these variables were extracted from the raster coverages produced for use in the Piping Plover Habitat BN as described in the "Methods_-Piping Plover Habitat Bayesian Network" section of this report. 


\section{Methods-Piping Plover Habitat Bayesian Network}

In this section, we describe intermediate and $\mathrm{BN}$ datasets associated with the Piping Plover Habitat BN. In the following subsections, BN datasets are those used directly in the Piping Plover Habitat BN. Intermediate datasets, although not used directly in the $\mathrm{BN}$, were used to derive $\mathrm{BN}$ datasets. Unless indicated otherwise, all steps were performed in ArcMap version 10.4 .

A note about study area boundaries and fill values: in the datasets described in subsequent sections, we confined analyses to predetermined study area boundaries. Study area boundaries were manually digitized in ArcMap following visual inspection of orthoimagery. For barrier islands (or example, Fire Island, Cedar Island), the boundary was drawn approximately $500 \mathrm{~m}$ offshore around the entire circumference of the island. For mainland beaches (for example, sites that are part of the Rhode Island NWR complex), we drew boundaries approximately $500 \mathrm{~m}$ offshore (on the ocean-facing side of the study area), approximately $500 \mathrm{~m}$ inland from the beach, and at the boundaries of where our collaborators monitored for piping plover nests. Although study area boundaries were relatively arbitrary, they included all terrestrial land considered in our analyses, and the final extent of a given study area does not affect the quality or completeness of the dataset as used for its intended purposes. For some spatial datasets and study areas, a lack of data in lidar or orthoimagery resulted in a "NoData" cell value within the confines of the study area boundary. We reclassified these cells with fill values (9999) so that they were not be excluded from subsequent analyses or from use in the Piping Plover Habitat BN. Cells outside study area boundaries were always given a "NoData" value of -9999 .

\section{Intermediate Datasets}

\section{Supervised Land Cover Classification}

We conducted a supervised land cover classification from orthoimagery to delineate substrate and vegetation characteristics. To better differentiate features with similar spectral signatures (such as water and the reflection from buildings), we performed independent subclassifications for marsh, vegetation and other features in the barrier island's interior, and bare sand and water. The results from subclassifications were later combined into a single classified image.

To divide the landscape into these subclassifications, we first created mask polygons representing each classification area through hand-digitization of the orthoimagery. For the marsh classification, we used previously hand-digitized polygons of marsh platforms (see subsection "Geomorphic Setting;" fig. 7A). For vegetation and inland features, we digitized a polygon around vegetated areas and the barrier interior by tracing a boundary between open sand and vegetation.
Areas of bare sand and water were delineated as the part of the study area not included by the marsh or vegetation polygons. Finally, we digitized areas of human development, including housing communities, commercial infrastructure, recreational facilities, major roads, and shoreline armoring (for example, jetties; fig. 7B). We converted the development polygons to a raster at the same resolution as the orthoimagery.

For each subclassification, we used orthoimagery to define training polygons for classes specific to that subclassification. Using those training polygons as inputs, we ran the interactive supervised classification routine in the Classification toolbar and clipped the resulting classification image to the extent of the given mask. We then masked out areas pertaining to the other mask polygons (marsh, vegetation, and development). The resulting classified image matched the extent of the given mask polygons and contained cells at the original resolution of the orthoimage (usually $1 \mathrm{~m}$ ).

For the marsh subclassification, we included training samples for the following classes: (1) water; (2) marsh, vegetation or unknown cover; (3) marsh, unvegetated sediment; and (4) marsh, shrub or forest (for example, fig. $7 C-D$ ). Development polygons were masked out of the final marsh subclassification. For inland vegetation, we included training polygons in the following classes: (1) water; (2) sand; (3) herbaceous vegetation or shrub with sparse to moderate cover ( $<20$ percent cover); (4) herbaceous vegetation or shrub with moderate to dense cover ( $>20$ percent cover); and (5) shrub or forest with moderate to dense cover. Marsh and development polygons were masked out of the final vegetation subclassification. Training samples for the sand and water classification represented only two classes: (1) sand and (2) water. Polygons for marsh, development, and vegetation were masked out of the final sand/water subclassification.

We merged the subclassification rasters for marsh, vegetation, and sand and water with the rasterized development layer into a single raster (hereafter, the "supervised classification"). We resampled the classified image to a 5- $\times 5-\mathrm{m}$ cell size and assigned "majority" as the interpolation method. In this method, the new 5- $\times 5$-m cell took on the most common value within a $3-\times 3$-cell moving neighborhood window. We also clipped the supervised classification to the extent of the study area.

In many instances, cells took on the value of "NoData" around the boundaries of the marsh, vegetation, and development masks when we merged individual subclassifications. We replaced these "NoData" values with the value held by the majority of cells in the surrounding $5-\times 5$-m cell window by using the Focal Majority filter in Raster Calculator.

The final supervised classification was a raster layer with a 5- $\times 5-\mathrm{m}$ cell size clipped to the extent of the study area. Cells took on one of nine possible values: water (value $=1$ ); sand (value $=2$ ); herbaceous vegetation or shrub with sparse to moderate cover (value $=9$ ); herbaceous vegetation or shrub with moderate to dense cover (value $=3$ ); shrub or forest with moderate to dense cover (value $=4$ ); marsh with open sediment (value $=11$ ); marsh with vegetation or unknown cover 
A

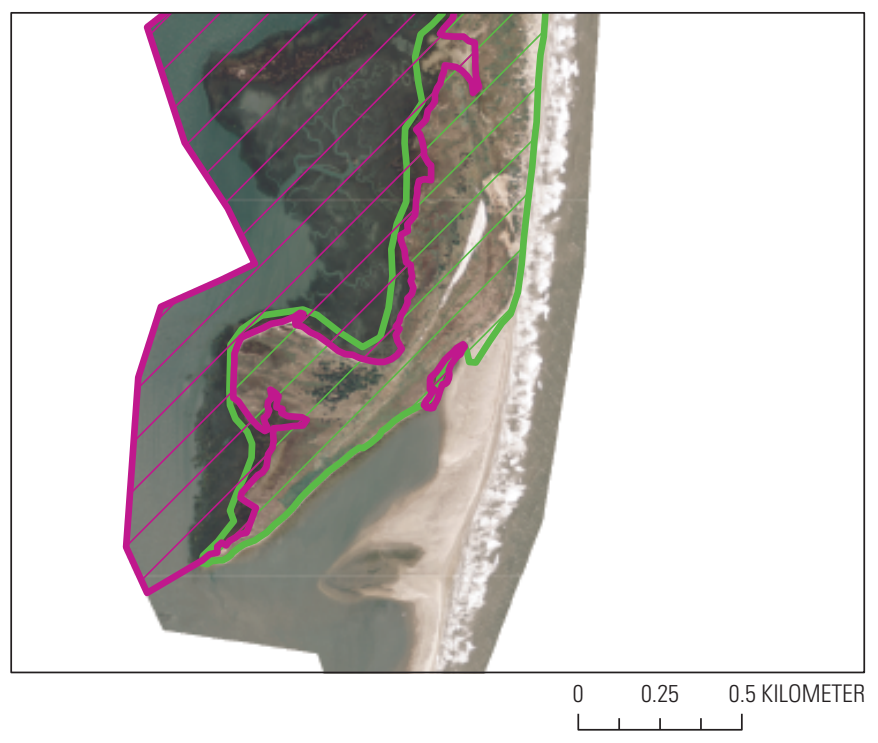

EXPLANATION

Marsh mask

Vegetation mask
B

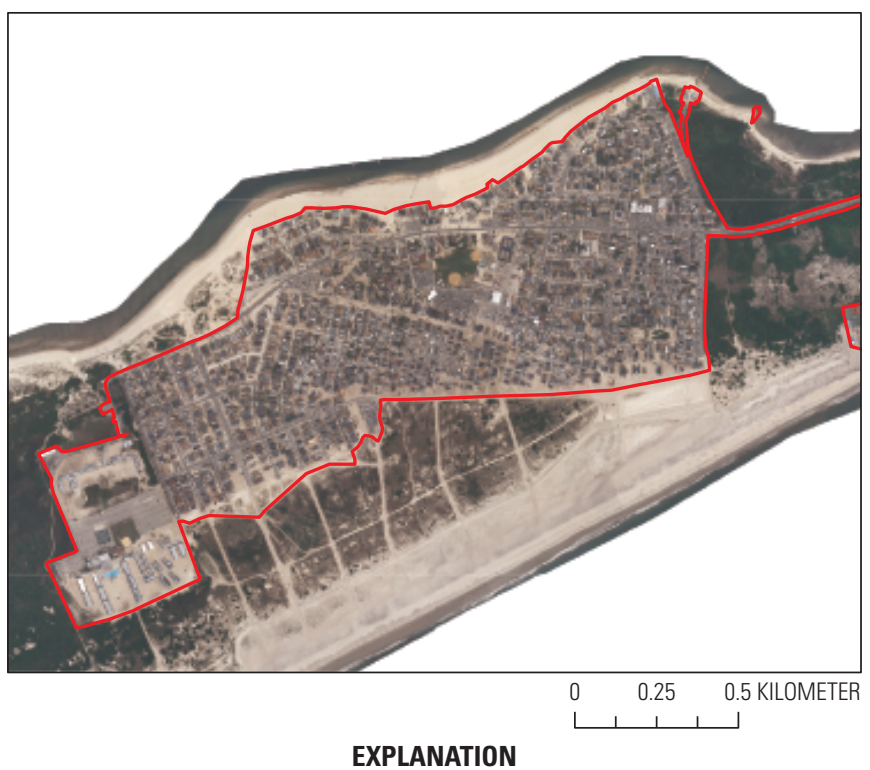

EXPLANATION
C

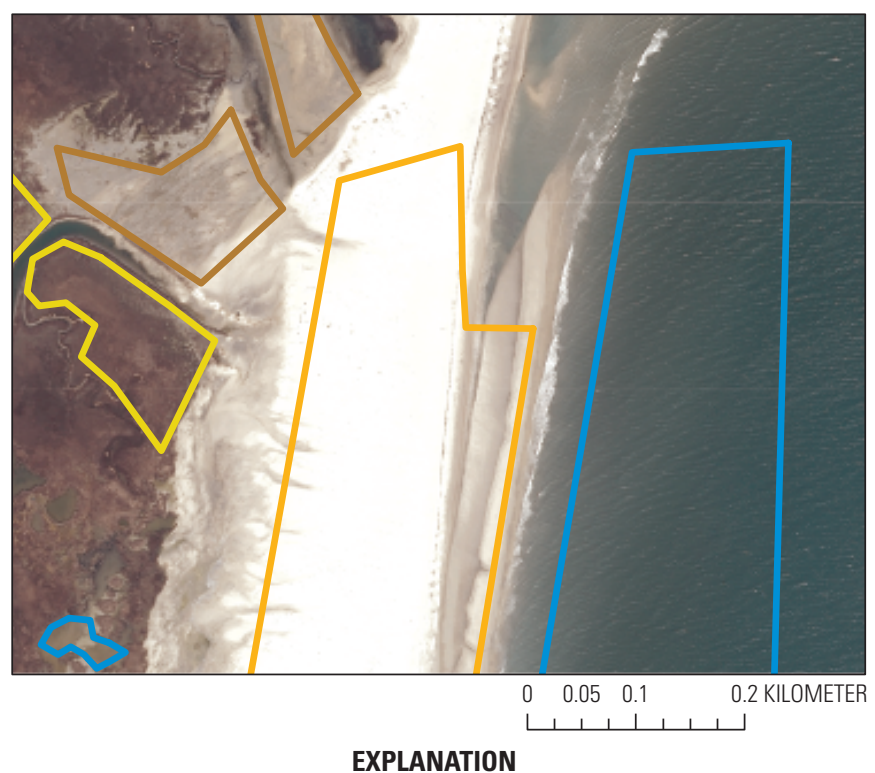

EXPLANATION

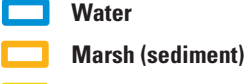

Marsh (vegetation/unknown)
D

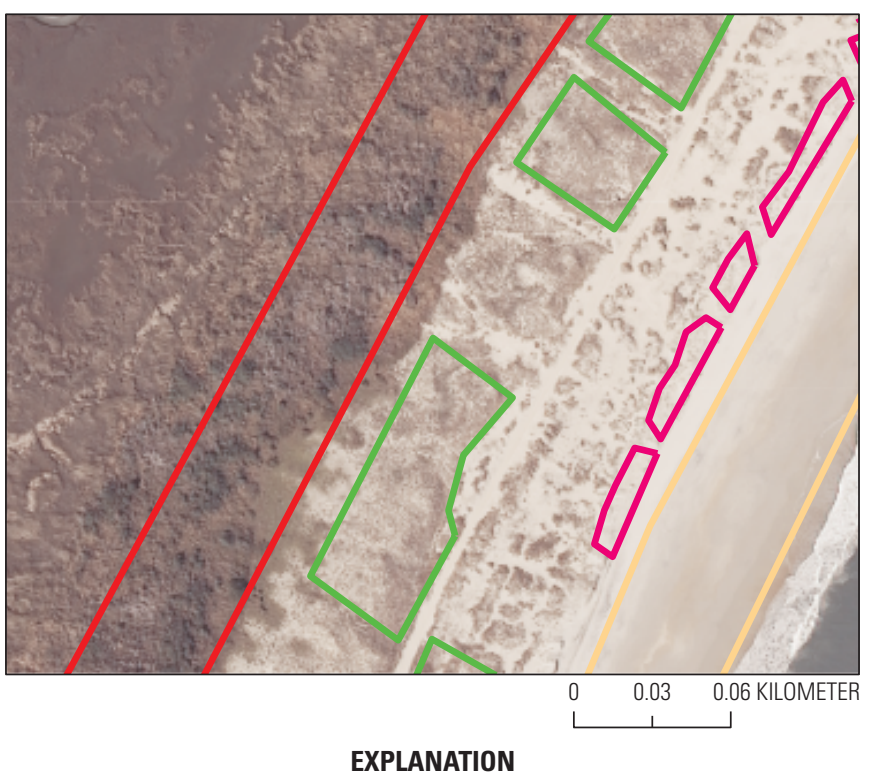

EXPLANATION

$\square$ Herb/shrub (sparse/mod)

Herb/shrub (mod/dense)

Sand

Shrub/forest

Figure 7. Masks and training polygons used as part of the supervised classification for each study area. The final classification was created by merging three subclassifications and one raster coverage, constrained by land cover-specific masks, for $A$, marsh areas, vegetated areas on the barrier's interior, areas of bare sand and water along the shoreline (regions not covered by masks), and $B$, developed areas. $C$ and $D$, examples of training polygons used in subclassifications. Study areas exemplified here include Wreck Island, Va. $(A)$; the Rockaway Peninsula, N.Y. $(B)$; and Cedar Island, Va. ( $C$ and $D)$. km, kilometer; mod/dense, moderate to dense vegetation density; sparse/mod, sparse to moderate vegetation density. 
(value $=7$ ); marsh with shrub or forest cover (value=14); and development (value $=10$ ).

\section{Foraging Shoreline}

The foraging shoreline is a polyline vector layer that indicates where piping plovers and their chicks could forage for terrestrial arthropods, invertebrates, marine worms, and other foods. Although piping plovers typically establish nests in washovers, backshore areas, and low elevation dune complexes (Strauss, 1990; Jones, 1997; Cohen and others, 2009; Kisiel, 2009; Maslo and others, 2011; Zeigler and others, 2017), adults often lead chicks to low-energy foraging grounds with moist substrates in bay-side intertidal zones (Cohen and Fraser, 2010; Maslo and others, 2012) and ephemeral pools (Fraser and others, 2005; Maslo and others, 2012) where terrestrial arthropods and invertebrates are more abundant (Cohen and others, 2009; Cohen and Fraser, 2010). To create the foraging shoreline layer, we overlaid the full island shoreline (see "Full Island Shoreline" in the "Methods-Barrier Island Geomorphology Bayesian Network" section of this report) on the orthoimage and manually removed sections of this shoreline that did not correspond to inlets, ponds, other ephemeral water bodies, or back-barrier sandy beaches. Here, the MHW ocean shoreline was not considered optimal foraging shoreline and was manually removed from the foraging shoreline vector for all study areas. Using the Editing toolbar, we then manually added foraging shorelines not already depicted by the full island shoreline based on visual inspection of orthoimagery. These manually added foraging shorelines were typically associated with inland waterways and interior ponds. This final layer was used in the creation of the distance to foraging raster coverage.

\section{Movement Cost Layer}

This intermediate raster coverage established boundaries to the movement of chicks (which are unable to fly before fledging) from ocean-side geomorphic settings, where nests are typically established, to interior and back-barrier foraging habitats (for example, sandy beaches, beaches along inlets, interior ponds). We combined the geomorphic setting, substrate type, vegetation type, and vegetation density raster coverages (see "Bayesian Network Datasets" in the "Methods-Piping Plover Habitat Bayesian Network" section of this report) into a single raster, where the attribute table represented all unique combinations of these characteristics. In this combined layer, we manually added a column "Cost" in which we assigned a cost value of 10 to every cell containing "development" (for substrate type, vegetation type, and vegetation density); "moderate," "dense," or "moderate or dense" (for vegetation density); or "water" (unless associated with the beach geomorphic setting; for substrate type). All remaining combinations of land cover were manually assigned a cost value of 0 . We created a new cost raster coverage from the "Cost" column of the combined raster by using the Lookup tool. After setting the output extent to that of the study area in the geoprocessing environment settings, we reclassified this layer such that every cell with a value of 10 took on a "NoData" value and every cell with a value of 0 took on a value of 1 .

The final movement cost layer indicated barriers (cell value $=$ "NoData") to movement where development, moderate to dense vegetation, and water existed. However, we allowed the potential for movement where the substrate type was water and the geomorphic setting was beach because we assumed that tidal fluctuations might allow adults and chicks to walk across temporarily exposed parts of the beach at low tide. In cases where the substrate type, vegetation type, or vegetation density were unknown (and the remaining known habitat variables did not contain a movement barrier), we allowed movement so as not to restrict what could be a movement corridor. This final raster layer (cell size: $5 \times 5 \mathrm{~m}$ ) was used in the creation of the distance to foraging $\mathrm{BN}$ dataset.

\section{Bayesian Network Datasets}

\section{Beach Width}

The beach width layer (BW) used in the Piping Plover Habitat BN is a raster coverage where the value of each cell is equivalent to the nearest known width of the backshore (that is, upper beach width, or the distance from the foredune toe to the MHW line) within $25 \mathrm{~m}$ alongshore (fig. 8A). This layer was converted from the transect-averaged upper beach width (uBW) metric (see subsection "Bayesian Network Datasets: Transect-Averaged Metrics" in the "Methods-Barrier Island Geomorphology Bayesian Network" section of this report) by assigning the upper beach width value at each transect to the nearest cell in the raster layer.

To assign the transect values to a raster coverage, we converted the non-overlapping supplemented transects (see subsection "Bayesian Network Datasets: Transect-Averaged Metrics") to a transect ID raster by using Euclidean allocation tool in the Spatial Analyst toolbox, with maximum distance set to $50 \mathrm{~m}$ and the source field set as the transect ID field. Next, beach width values from each transect were assigned to the cells that represented that transect by using the Join Field tool. Because transects were spaced roughly $50 \mathrm{~m}$ alongshore, the nearest transect was less than $25 \mathrm{~m}$ from the cell. Beach width was calculated for the full transect such that the entire crossisland swath pertaining to one transect had the same beach width value. Finally, we set the processing extent to that of the study area boundary (in environment settings) and reclassified the value of each cell that did not already have a beach width value to a fill value of 9999 .

This variable was only used in early versions of the Piping Plover Habitat BN. Models of piping plover habitat that considered beach width were developed for Fire Island (N.Y.), Rockaway Peninsula (N.Y.), Forsythe NWR (N.J.), and Cedar Island (Va.). Therefore, a beach width spatial dataset 
A

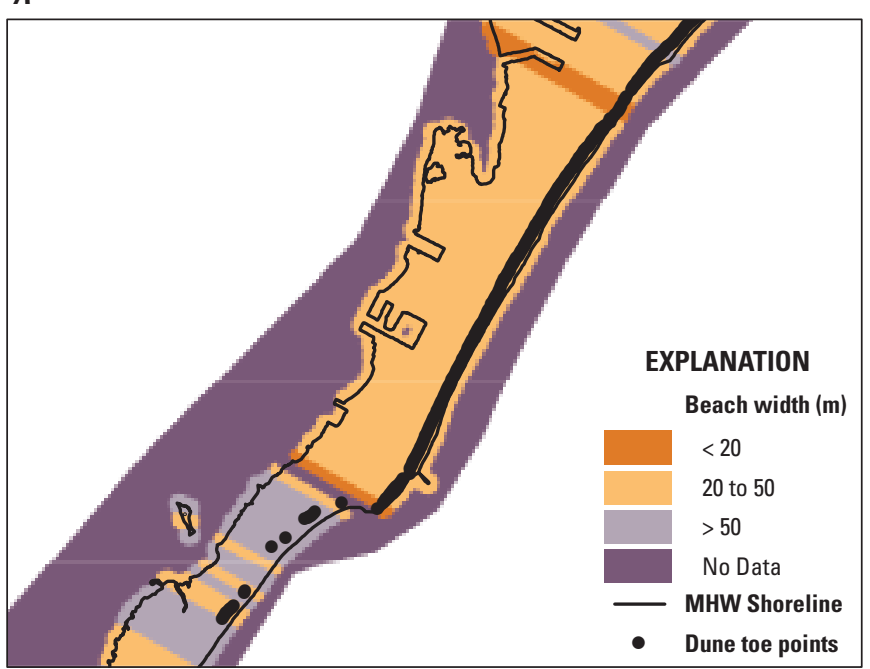

B

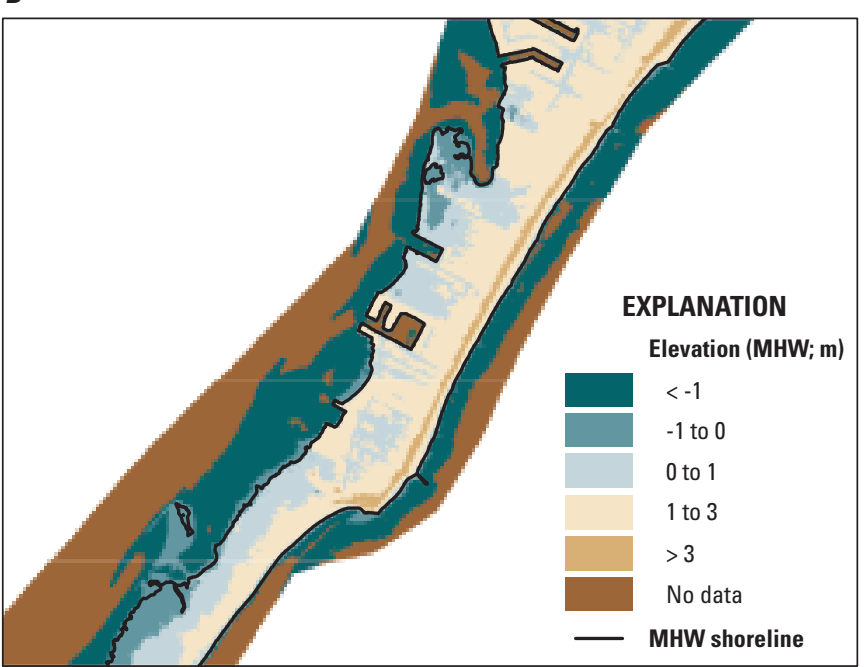

C

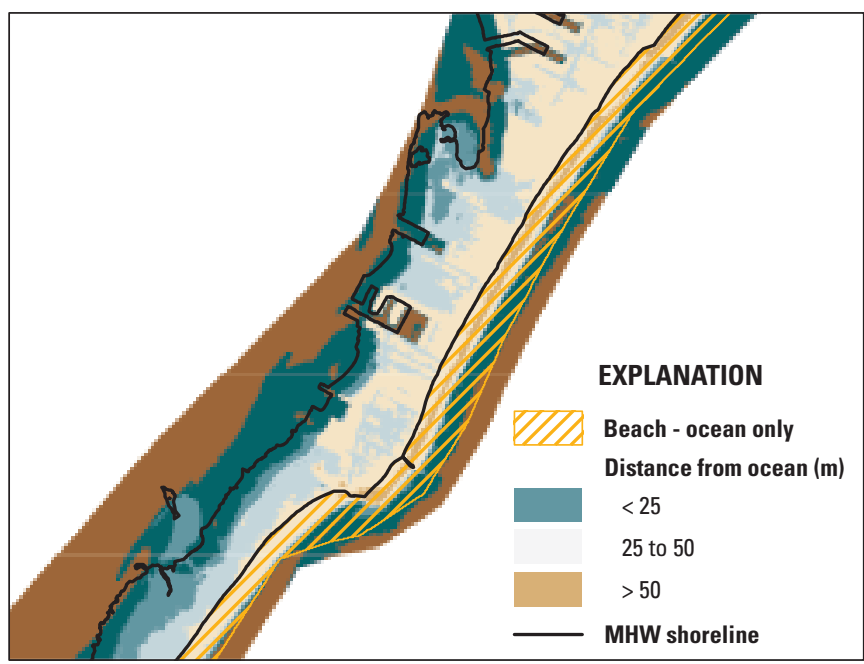

D

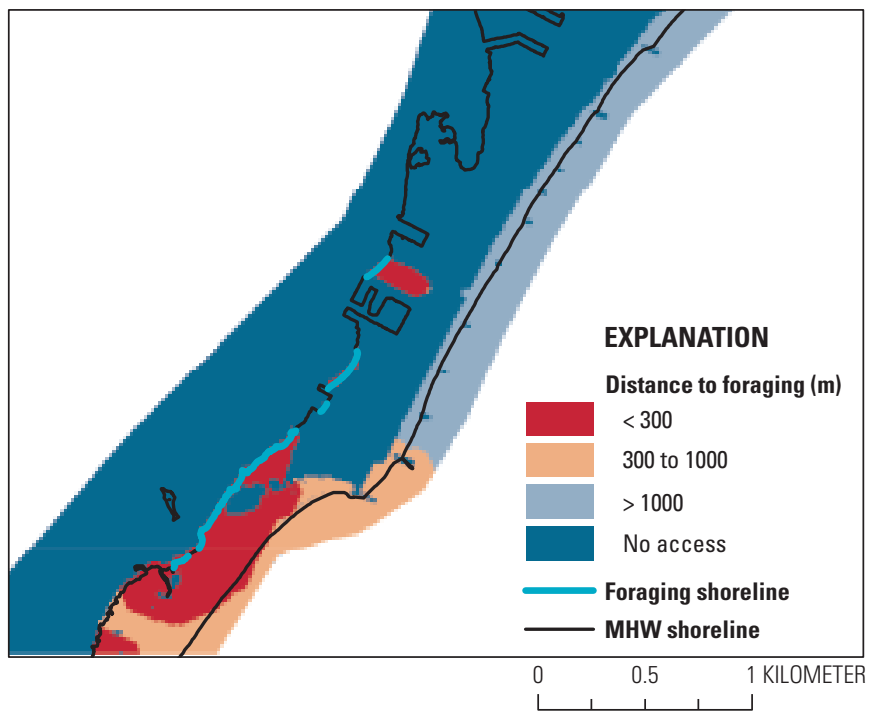

Figure 8. Examples of final products used in the Piping Plover Habitat Bayesian network, depicting raster coverages for $A$, beach width, $B$, elevation, $C$, distance from ocean, and $D$, distance to foraging for Pullen and Long Beach Islands, New Jersey. km, kilometer; $\mathrm{m}$, meter; MHW, mean high water. 
is included in the data release associated with this report for these study areas (Sturdivant and others, 2019). The data release for all other study areas does not contain a beach width raster dataset; however, an uBW metric is associated with each transect for all 21 study areas described in this report.

\section{Elevation (Corrected for Mean High Water)}

The elevation layer (ElevMHW) used in the Piping Plover Habitat $\mathrm{BN}$ is a raster layer, where the value of every $5-\times 5-\mathrm{m}$ cell is the MHW-adjusted elevation at that location (fig. $8 B$ ). We converted the DEM GeoTIFF file to a raster grid in ArcMap in the study area's extent (as set in the geoprocessing environment settings). We then resampled the resolution of the DEM (usually $1 \mathrm{~m}$ ) to $5 \mathrm{~m}$ by using the Resample tool with bilinear interpolation, which calculates the value of each pixel by averaging (weighted for distance) the values of the surrounding four cells. We subtracted the MHW offset value for the given study area in the Raster Calculator (see subsection "Mean High Water Offsets" in the "Initial Data Sources" section of this report). We reclassified the value of each cell that did not already have an elevation value to a fill value of 9999 .

\section{Distance to Ocean}

The distance to ocean layer (DisOcean) is a raster layer, where the value of every 5- $\times 5$-m cell is the Euclidean distance from the center of that cell to the nearest point on the ocean MHW shoreline (fig. 8C). To create this layer, we started by locating the "ocean" boundary in the study area. Using the geomorphic settings GeoTIFF (see "Geomorphic Setting" subsection), we selected all raster cells defined as "beach" and exported the selected features as a polygon using the "Raster to Polygon" conversion tool. Here, "beach" is defined as the area between the shoreline (see "Full Island Shoreline" subsection) and the study area boundary. In an Edit session in ArcGIS, we used the "Cut Polygons" tool to manually clip the beach polygon so that only the portion of the polygon on the ocean-facing side of the barrier island remained. The MHW shoreline points (Doran and others, 2017) were referenced to identify the extent of the ocean-facing portion of the beach and its shoreline. For these purposes, this clipped beach area from the MHW shoreline seaward to the edge of the study area was considered the ocean boundary. In the instance of the Monomoy National Wildlife Refuge, we indicated that the entire shoreline encompassing the peninsula was considered to be ocean shoreline because of irregular shape and position of this study area. Using the Euclidean Distance tool, we created a raster layer with a $5 \times 5 \mathrm{~m}$ cell size that measured the straight-line distance from each cell within the study area to the closest cell in the clipped beach polygon (considered the ocean boundary). Cells landward of the MHW shoreline received a positive distance to ocean value and those seaward of the MHW shoreline received a value of $0 \mathrm{~m}$.

\section{Distance to Foraging}

This raster coverage (DisMOSH) displayed the least cost path distance from the center of every cell to the nearest lowenergy, non-ocean foraging area containing moist substrates (fig. 8D). We used the Path Distance tool in ArcToolbox, specifying the foraging shoreline vector layer (see subsection "Foraging Shoreline") as the "Source data" and the movement cost layer (see subsection "Movement Cost Layer") as the "Input cost layer." We set the output extent to that of the study area in the geoprocessing environment settings and specified a cell size of $5 \mathrm{~m}$. This tool calculates the least accumulative cost distance for each cell to the nearest source (foraging shoreline layer) while accounting for surface distance and horizontal cost factors (movement cost layer). Here, cells with a "NoData" value are considered movement barriers, and distance values account for routes that avoid these obstacles. We then reclassified this path distance layer such that each cell previously classified as "NoData" (within the limits of the study area boundary) took on the value of 99999 . We assumed that foraging areas were inaccessible from these cells, which were designated as barriers to movement in the movement cost layer.

\section{Geomorphic Setting}

The geomorphic setting raster layer (GeoSet; 5- $x$ 5-m resolution) classified each barrier island or mainland beach on the basis of the dominant coastal geomorphological features found along the U.S. Atlantic coast (fig. 9). Cells took on one of seven possible categorical values: beach, backshore, dune, washover, barrier interior, marsh, and ridge/swale (see table 4 for definitions). We first delineated the boundaries of individual features (for example, the edges of washover fans) as polygons and then converted polygons for the seven geomorphological settings to a single raster image. We assigned each geomorphic feature an identification value ("value") and a priority value ("priority;" lower numbers indicated lower priority), which was used to weight the features during merging.

To delineate the boundaries of individual features, we first hand-digitized the boundaries of the marsh setting (value $=6$, priority $=6$ ). The bay-side edges of marsh polygons were delineated to extend beyond the study area boundary and include areas of open water adjacent to marsh platforms. Next, we delineated the beach setting (value $=1$, priority $=5$ ) by masking out the full island shoreline and marsh polygons from the study area boundary polygon with the Erase tool. Therefore, the beach setting encompassed all areas outside of the MHW shoreline that were not designated as marsh. Together, the beach and marsh polygons covered the outermost edges of the study area (fig. $9 A$ ).

To delineate the dune setting (value $=3$, priority $=7$ ) we used the DEM (displayed with color classes corresponding to 1-m equal intervals), foredune positions, and orthoimagery as guides. We digitized the rear of dune complexes such that the boundary fell inland of foredune crest points (if present) and 
A

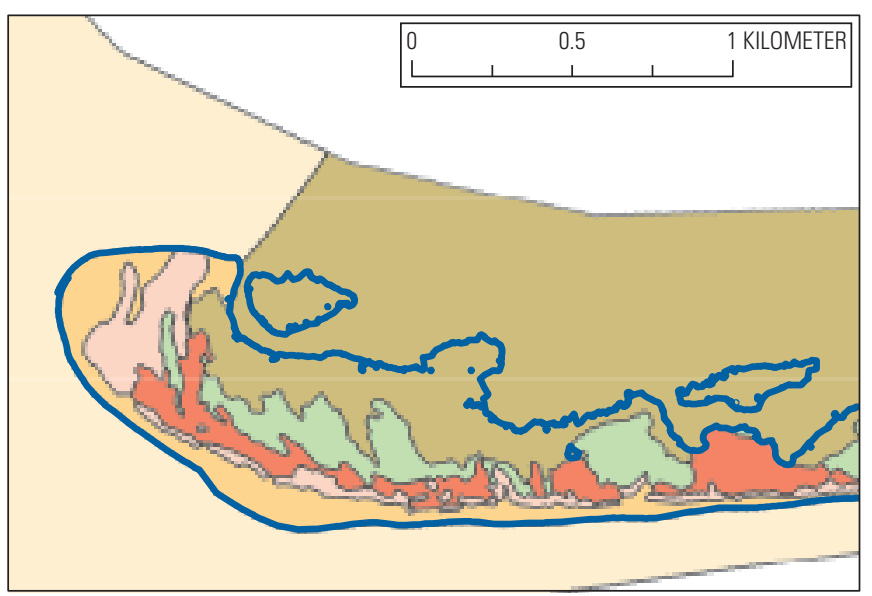

EXPLANATION

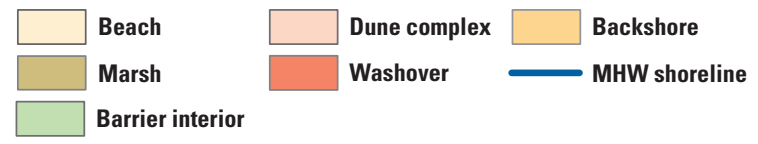

C

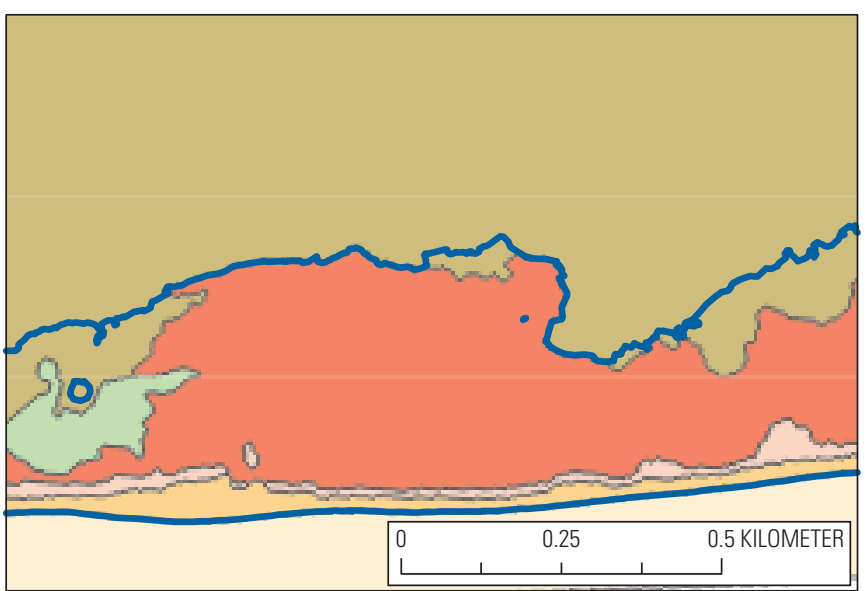

EXPLANATION

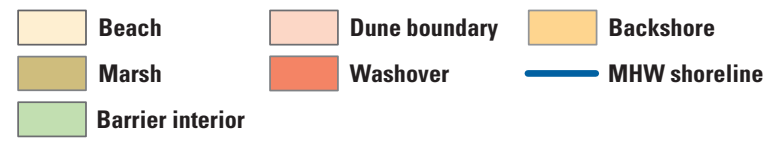

B

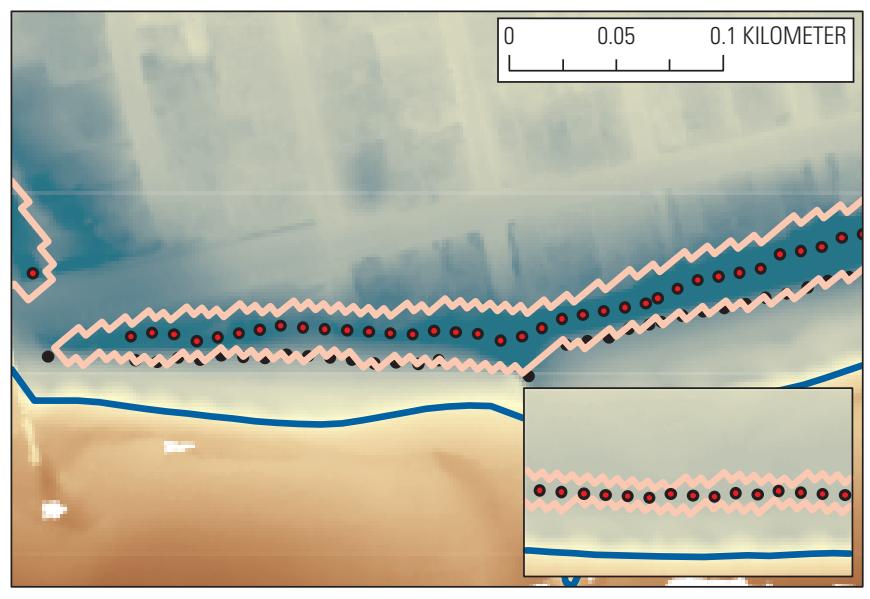

EXPLANATION

Dune boundary $\quad$ Dune crest points Lidar $(\mathrm{m})$

MHW shoreline $\quad$ Dune toe points
D

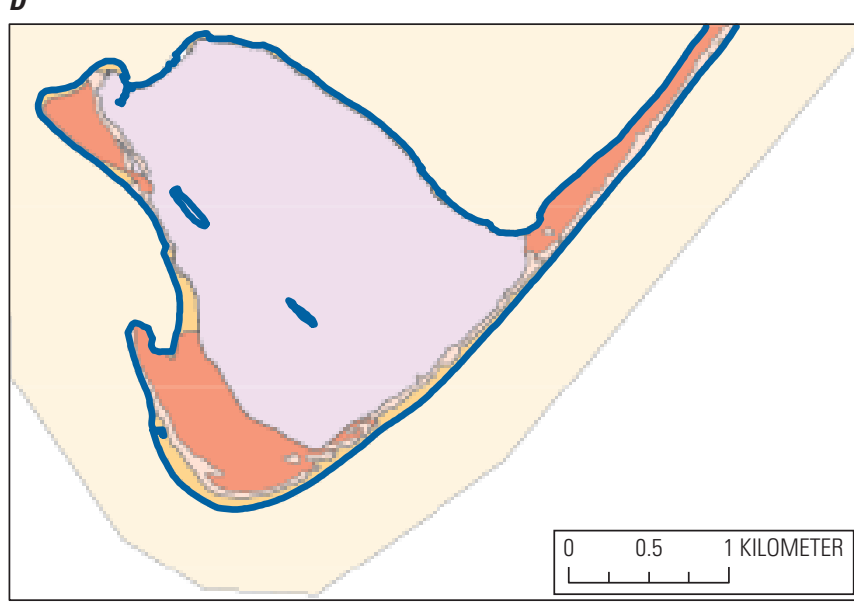

EXPLANATION

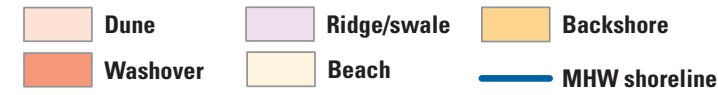

Figure 9. Examples of hand-digitized polygons depicting geomorphic settings. Polygons were digitized through visual inspection of orthoimagery and later combined to create a geomorphic settings raster layer used in the Piping Plover Habitat Bayesian network. Geomorphic settings included beach, backshore, marsh, barrier interior, dune complex, washover, and ridge/swale. $A-C$, Edwin $B$. Forsythe National Wildlife Refuge on Long Beach Island, New Jersey; $D$, Chincoteague National Wildlife Refuge on Assateague Island, Virginia. The detail inset in $B$ shows an example dune delineation around foredune crest points in the absence of foredune toe points or obvious changes in elevation. km, kilometer; m, meter; MHW, mean high water. 
along a decrease in elevation visible in the DEM. The front of the dune was drawn such that the boundary passed through foredune toe points (if present) and coincided with a decrease in elevation noticeable in the DEM. We used the snapping feature in the Editing toolbar to ensure that the front boundary of dune complexes followed foredune toe points (fig. 9B). In some instances, particularly in washovers, foredune datasets indicated foredune crests without either foredune toe points or visibly obvious changes in elevation in the DEM. In these cases, we hand-digitized the dune boundary such that it tightly encompassed the foredune crest points (fig. 9B, detail).

Boundaries of the remaining geomorphic features were hand-digitized from the orthoimagery and in reference to boundaries already created for beach, marsh, and dunes. The inland boundary of the backshore setting (value $=2$, priority $=4$ ) was digitized such that it overlapped with the dune polygons but did not extend past the most landward boundary of the dune. When dunes were not present, the inland boundary of the backshore setting abutted areas of dense vegetation as observed in the orthoimagery. We extended the backshore polygon boundary seaward beyond the MHW shoreline or beyond the boundary of marsh in the case of the back barrier (fig. $9 \mathrm{C}$ ). The characteristic fan-shaped boundaries of washovers (value $=4$, priority $=3$ ) were manually digitized to overlap with the marsh polygons along the back barrier and with the boundaries of dune complexes on the seaward side of the island. Where dunes were not present, we referred to the orthoimagery to delineate the washover boundary along visible areas of wrack (fig. 9C). We hand-digitized polygons for ridge/swale complexes (value $=7$, priority $=2$ ) at the boundary between sand and vegetation (fig. 9D). For the final geomorphic setting for barrier interior (value $=5$, priority $=1$ ), we erased all other geomorphic settings (beach, backshore, dune, washover, marsh, and ridge/swale complexes) from the study area polygon by using the Erase tool. As a result, the barrier interior setting was present only in the absence of any other geomorphic setting.

We merged the individual polygon files for beach, backshore, dune, washover, barrier interior, marsh, and ridge/ swale into a single shapefile and closed any remaining small gaps between polygons by using the Integrate tool (with distance $=1 \mathrm{~m}$ ). We then converted the merged polygon shapefile to a raster with a $5-\mathrm{m}$ cell size, using the priority value for each geomorphic setting type in the attribute table to determine which geomorphic setting type took precedence when two or more settings overlapped (in other words, a raster cell took the value of the feature with the highest priority value). The final geomorphic setting raster provided a coverage of the geomorphic features present within a given study area, with every 5- $\times 5-\mathrm{m}$ cell categorized as one of the seven possible geomorphic settings.

\section{Substrate Type}

The substrate type raster layer (SubType; 5- $\times 5$-m resolution) classified the major substrate types found on barrier islands and mainland beaches along the U.S. Atlantic coast. It was derived from the supervised land cover classification (see subsection "Supervised Land Cover Classification") by reclassifying the original classified values to the substrate type values (table 5; for example, "marsh, vegetation or unknown cover" was reclassified to "mud/peat"). Each cell in the final raster coverage was characterized by one of eight possible values: (1) sand, (2) shell/gravel/cobble, (3) mud/peat, (4) water, (5) unknown (or no data), (6) development, (7) sand or shell/ gravel/cobble, and (8) sand or mud/peat (fig. 10A).

In the Barrier Island Geomorphology and Piping Plover Habitat BNs, substrate types considered include (1) predominantly sand ("sand"); (2) a mixture of sand and shell

Table 5. Reclassification values used to translate the original supervised classification to raster layers depicting substrate type, vegetation type, and vegetation density.

\begin{tabular}{llll}
\hline \multicolumn{1}{c}{ Supervised classification } & \multicolumn{1}{c}{$\begin{array}{c}\text { Substrate type } \\
\text { (cell value) }\end{array}$} & \multicolumn{1}{c}{$\begin{array}{c}\text { Vegetation type } \\
\text { (cell value) }\end{array}$} & $\begin{array}{c}\text { Vegetation density } \\
\text { (cell value) }\end{array}$ \\
\hline No data & Unknown (9999) & Unknown (9999) & Unknown (9999) \\
Water & Water (4444) & None (11) & None (111) \\
Sand & Sand or shell/gravel/cobble (7777) & None or herbaceous (77) & None or sparse (666) \\
Herbaceous or shrub (sparse to moderate cover) & Sand or shell/gravel/cobble (7777) & Herbaceous or shrub (88) & Sparse or moderate (777) \\
Herbaceous or shrub (moderate to dense cover) $)$ & Sand or shell/gravel/cobble (7777) & Herbaceous or shrub (88) & Moderate or dense (888) \\
Shrub or forest & Unknown (9999) & Shrub or forest (99) & Moderate or dense (888) \\
Marsh (sediment) & Sand or mud/peat (1000) & None or herbaceous (77) & None or sparse (666) \\
Marsh (vegetation or unknown cover) & Mud/peat (3333) & Unknown (9999) & Unknown (9999) \\
Marsh (shrub or forest) & Unknown (9999) & Shrub or forest (99) & Moderate or dense (888) \\
Development & Development (6666) & Development (55) & Development (555) \\
\hline
\end{tabular}



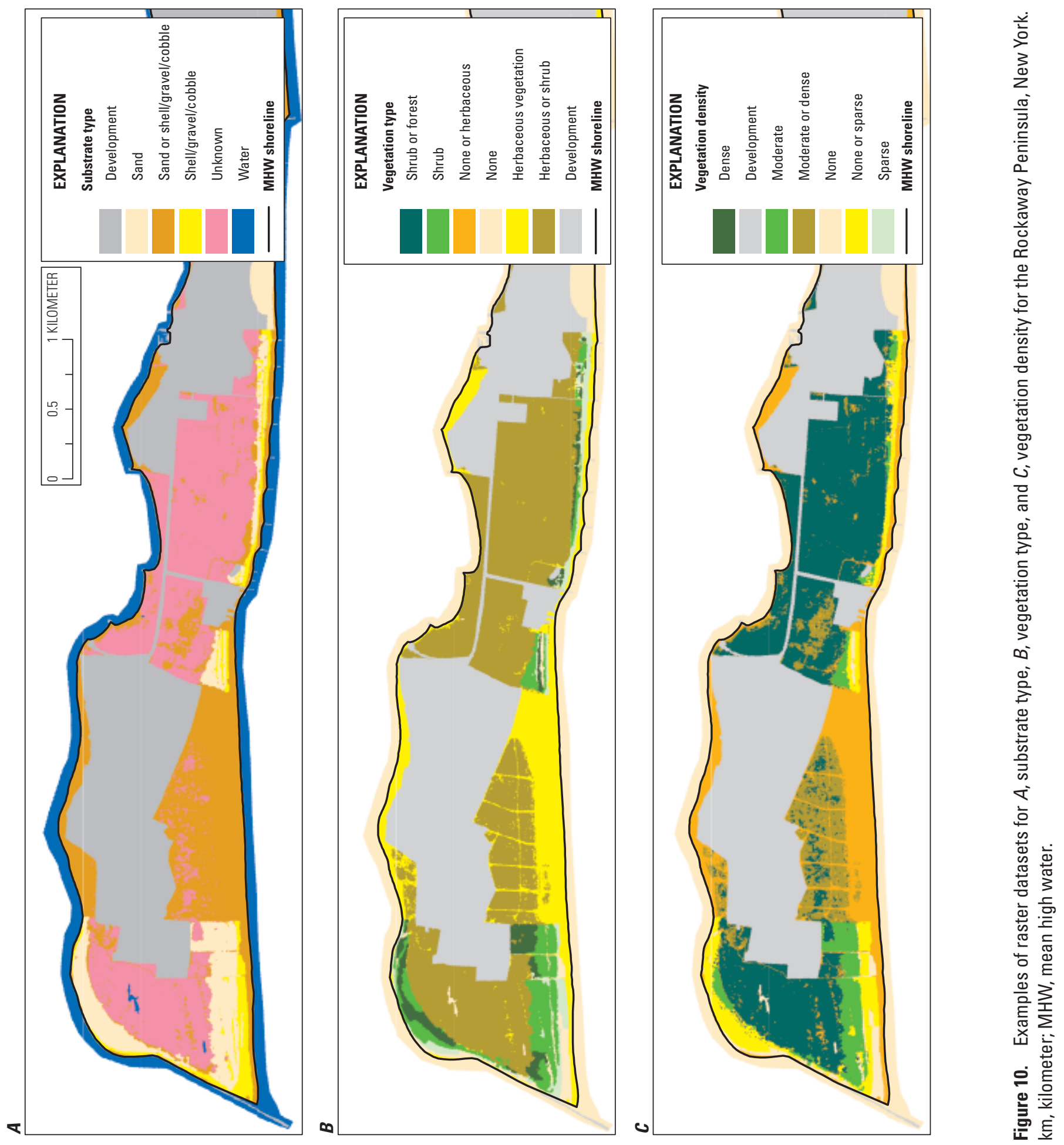
fragments, gravel, or cobble ("shell/gravel/cobble"); (3) mud or peat ("mud/peat"); (4) water ("water"); or (5) development ("development"). See table 4 for categorical definitions. However, it was often difficult to determine the exact nature of substrate by using remote datasets. For example, an area that looked like bare sand in the orthoimagery might actually contain a mixture of sand and shell fragments. To address this uncertainty, we allowed cells to be classified as more than one substrate type. In the preceding example, cells that were classified as sand during the supervised classification but might contain a mixture of sand and shell/gravel/cobble were always reclassified as "sand or shell/gravel/cobble" (value=7777) unless a more detailed substrate dataset was available.

The BNs used in this study are able to process more than one categorical value for the same variable. When multiple values are presented to the network in this way, the network essentially splits the identity of that variable. For example, a raster cell with a value of 7777 denotes substrate that is "sand or shell/gravel/cobble." When this information is processed from the spatial dataset through the Piping Plover Habitat BN, the network assigns a probability of 50 percent to the variable being sand and a probability of 50 percent to the variable being shell/gravel/cobble instead of a 100-percent probability of the variable being one of those classes alone. This information is then propagated through all prior probability distributions as the network calculates the probability that the specific combination of all habitat variables is associated with piping plover nesting habitat. In instances where the substrate type is completely unknown (value $=9999$ in the substrate type layer), the Piping Plover Habitat BN considers the probability of that variable's identity based on the underlying probability distribution for that variable (which is calculated directly from the training data). In this way, a given cell could have a single value in the raster layer but represent multiple discrete conditions or characteristics in the BN. This situation also arises in the vegetation type and vegetation density raster layers.

We made one additional modification to the substrate type layer as we created it from the supervised classification. In instances where a raster cell was classified as "beach" in the geomorphic settings layer, we reclassified those cells as "water" in the substrate type layer. We did this because cells characterized as beach fell seaward of the MHW shoreline and thus could be submerged, depending on the tide stage.

Additional information on substrate characteristics was available in a shapefile of land cover types for the Rockaway Peninsula study area (Zeigler and others 2017). This shapefile was created by H. Abouelezz (National Park Service, unpub. data, 2013) with a hand-held Global Navigation Satellite System receiver ("GNSS dataset"). For the Rockaway Peninsula in 2014, we further refined the substrate type layer by reclassifying the polygons in the GNSS dataset to match our substrate type categories (sand, shell/gravel/cobble, mud/peat, water, or development). We converted the reclassified GNSS dataset to a raster and combined this raster with the substrate type layer prior to any manual modification using the Combine tool. We then reclassified this combined raster such that the identity of cells with GNSS data took precedence over those with only supervised classification data.

\section{Vegetation Type}

The vegetation type layer is a raster layer (VegType; 5- $\times 5-\mathrm{m}$ resolution) that depicts the major vegetation classes found on barrier islands along the U.S. Atlantic coast (fig. 10B). Each cell was characterized by one of nine possible values: (1) none, (2) herbaceous, (3) shrub, (4) forest, (5) unknown (or no data), (6) development, (7) none or herbaceous, (8) herbaceous or shrub, or (9) shrub or forest. This coverage was derived from the supervised land cover classification (see subsection "Supervised Land Cover Classification") by reclassifying the original classified values to vegetation type values (table 5). For example, "herbaceous or shrub (sparse to moderate cover)" was reclassified to "herbaceous or shrub" for the vegetation type layer.

In the Barrier Island Geomorphology and Piping Plover Habitat BNs, vegetation types considered include (1) no vegetation ("none"), (2) herbaceous vegetation ("herbaceous"), (3) shrubby vegetation ("shrub"), (4) forest ("forest"); or (5) development ("development"). See table 4 for the definitions of these categories. However, as in the substrate type layer, we allowed some cells to take on more than one vegetation type value in the geospatial raster layer to address uncertainty in the supervised classification. For example, cells that were described as sand in the supervised classification were reclassified as "none or herbaceous" (value $=77$ ) in the vegetation type layer. Such cells were given a 50-percent probability of having no vegetation and a 50-percent probability of having herbaceous vegetation when processed through the Piping Plover Habitat BN.

For the vegetation type layer depicting the Rockaway Peninsula study area in 2014, we further refined vegetation characteristics by using the GNSS dataset (referenced under the "Substrate Type" subsection). We reclassified polygons in the GNSS dataset to match categories considered for vegetation type (none, herbaceous, shrub, forest, or development). We converted the reclassified GNSS dataset to a raster and combined this raster with the vegetation type layer prior to manual modification. We then reclassified this raster such that the identities of cells with GNSS data took precedence over those with only supervised classification data.

\section{Vegetation Density}

The vegetation density raster layer (VegDen; $5-\times 5-\mathrm{m}$ resolution) approximated the percentage cover of vegetation across a barrier island (fig. 10C). Each cell was characterized by one of nine possible values: (1) none, (2) sparse, (3) moderate, (4) dense, (5) unknown (or no data), (6) development, (7) none or sparse, (8) sparse or moderate, or (9) moderate or dense. This coverage was derived from the supervised land cover classification (see subsection "Supervised Land Cover 
Classification") by reclassifying the original classified values to vegetation density values (table 5). For example, "herbaceous or shrub (sparse to moderate cover)" was reclassified to "sparse or moderate" for the vegetation density layer.

In the Barrier Island Geomorphology and Piping Plover Habitat BNs, vegetation densities considered include (1) no vegetation ("none"); (2) sparse vegetation, <20 percent cover ("sparse"); (3) moderate vegetation, 20 to 90 percent cover ("moderate"); (4) dense vegetation, $>90$ percent cover ("dense"); or (5) development ("development"). See table 4 for categorical definitions. However, as in the substrate type layer, we allowed some cells to take on more than one vegetation density value in the geospatial raster layer to address uncertainty in the supervised classification. For example, cells that were described as sand in the supervised classification were reclassified as "none or sparse" (value $=666$ ) in the vegetation density layer. Such cells were given a 50-percent probability of having no vegetation and a 50-percent probability of having sparse vegetation when processed through the Piping Plover Habitat BN.

For the vegetation density layer depicting the Rockaway Peninsula study area in 2014, we further refined vegetation characteristics by using the same GNSS dataset as for the substrate type (H. Abouelezz, National Park Service, unpub. data, 2013). We reclassified polygons in the GNSS dataset to match categories considered for vegetation density (none, sparse, moderate, dense, or development). We converted the reclassified GNSS dataset to a raster and combined this raster with the vegetation density layer prior to any manual modification using the Combine tool. We then reclassified this raster such that the identity of cells with GNSS data took precedence over those with only supervised classification data.

\section{Validation of Select Bayesian Network Datasets}

To validate the raster layers for geomorphic setting, substrate type, vegetation type, and vegetation density, we followed the protocol recommended by the U.S. National Park Service (Lea and Curtis, 2010). We conducted validation testing for a subset of our study areas (hereafter, "validation study areas;" table 6). For each validation study area and year, we used raster layers for geomorphic setting, substrate type, vegetation type, and vegetation density described in the "Methods-Piping Plover Habitat Bayesian Network" section of this report. These raster layers were associated with 2014 landscape conditions (that is, layers were created from 2014 orthoimagery; table 2), with the exception of layers for the Fire Island study area, which were associated with 2015 orthoimagery and conditions.

We used a dataset of landscape conditions recorded in situ at piping plover nests and at random locations for validation. This dataset, referred to as the "iPlover dataset," and methods employed in its collection are described in more
Table 6. Study areas and associated data points used to validate spatial analyses that resulted in raster layers for geomorphic setting, substrate type, vegetation type, and vegetation density.

[Biogeomorphic characteristics were described at each point location in 2014 (2015 for Fire Island) in situ using the iPlover data collection application, and points from these study areas and years are a subset of the full iPlover dataset available in Sturdivant and others (2016). NWR, National Wildlife Refuge; NS, National Seashore]

\begin{tabular}{lc}
\hline \multicolumn{1}{c}{ Study area } & $\begin{array}{c}\text { Number } \\
\text { of points }\end{array}$ \\
\hline Parker River NWR (Plum Island and Crane Beach; Mass.) & 20 \\
Monomoy NWR (Mass.) & 48 \\
Fire Island NS (N.Y.) & 69 \\
Rockaway Peninsula (including Gateway National & 39 \\
$\quad$ Recreation Area; N.Y.) & \\
Forsythe NWR (Long Beach and & 78 \\
$\quad$ Pullen islands; N.J.) & 76 \\
Assateague Island NS and Chincoteague NWR & 28 \\
$\quad$ (Assateague Island; Md./Va.) & 1 \\
Cedar Island (Va.) & 37 \\
Cobb Island (Va.) & 18 \\
Assawoman/Wallops Island (Va.) & 39 \\
Smith Island (Va.) & 3 \\
Metompkin Island (Mass.) & 3 \\
Ship Shoal Island (Va.) & 1 \\
Wreck Island (Va.) & 43 \\
Fisherman Island NWR (Va.) & 503 \\
Cape Lookout NS (Shackleford, North Core, and & \\
$\quad$ South Core Banks; N.C.) & \\
Total & \\
\hline
\end{tabular}

detail elsewhere (Thieler and others, 2016; Zeigler and others, 2017). From the full iPlover dataset (Sturdivant and others, 2016), we selected all iPlover points recorded at validation study areas (table 6) in the year 2014 (for Fire Island, points recorded in the year 2015). We removed all points for which the biogeomorphic classification was "unknown" for the insitu classification. This resulted in 501 validation points for the evaluation of geomorphic setting, 490 for substrate type, 482 for vegetation type, and 482 for vegetation density.

We overlaid iPlover validation points on a mosaic of the geomorphic setting raster layers for all validation study areas and extracted the geomorphic setting value to each iPlover data point (Extract Values to Points tool; table 6). Once all points were assigned both in-situ and remote classification values, we created a contingency table showing the proportion of points $\left(p_{i j}\right)$ that were characterized by column $j$ (in-situ classification) and row $i$ (remote raster classification; table 7). In this table, the values along the diagonal indicated the proportion of points that were classified correctly in the raster layer. We calculated accuracy as follows: 
Table 7. Contingency table for validating geomorphic setting raster layers created for each study area used to validate spatial analyses.

[For validation, we used biogeomorphic characteristics observed in situ at point locations contained in the iPlover dataset available in Sturdivant and others (2016). Cell values indicate the proportion of points that were classified as column $j$ (based on the remotely-classified raster layer) and as row $i$ (based on in-situ observations). Cell values along the diagonal (gray shading) indicate the proportion of points classified correctly in the raster layer. XX, not applicable]

\begin{tabular}{lcccccccc}
\hline \multirow{2}{*}{$\begin{array}{c}\text { In-situ } \\
\text { classification }\end{array}$} & Beach & $\begin{array}{c}\text { Back- } \\
\text { shore }\end{array}$ & Dune & Washover & $\begin{array}{c}\text { Barrier } \\
\text { interior }\end{array}$ & Marsh & $\begin{array}{c}\text { Ridge/ } \\
\text { swale }\end{array}$ & Row total \\
\cline { 2 - 9 } Beach & 0.01 & 0.06 & 0.00 & 0.02 & 0.00 & 0.00 & 0.00 & 0.09 \\
Backshore & 0.00 & 0.09 & 0.00 & 0.04 & 0.00 & 0.00 & 0.00 & 0.13 \\
Dune & 0.00 & 0.07 & 0.05 & 0.08 & 0.01 & 0.00 & 0.00 & 0.21 \\
Washover & 0.00 & 0.01 & 0.04 & 0.26 & 0.00 & 0.00 & 0.00 & 0.31 \\
Barrier interior & 0.00 & 0.01 & 0.04 & 0.11 & 0.02 & 0.01 & 0.00 & 0.19 \\
Marsh & 0.01 & 0.00 & 0.00 & 0.00 & 0.00 & 0.04 & 0.00 & 0.05 \\
Ridge/swale & 0.00 & 0.00 & 0.00 & 0.01 & 0.00 & 0.00 & 0.00 & 0.01 \\
\cline { 2 - 9 } Column total & 0.02 & 0.24 & 0.13 & 0.52 & 0.03 & 0.05 & 0.00 & $\mathrm{XX}$ \\
Overall accuracy & 0.47 & $\mathrm{XX}$ & $\mathrm{XX}$ & $\mathrm{XX}$ & $\mathrm{XX}$ & $\mathrm{XX}$ & $\mathrm{XX}$ & $\mathrm{XX}$ \\
Chance agreement & 0.23 & $\mathrm{XX}$ & $\mathrm{XX}$ & $\mathrm{XX}$ & $\mathrm{XX}$ & $\mathrm{XX}$ & $\mathrm{XX}$ & $\mathrm{XX}$ \\
Kappa coefficient & 0.31 & $\mathrm{XX}$ & $\mathrm{XX}$ & $\mathrm{XX}$ & $\mathrm{XX}$ & $\mathrm{XX}$ & $\mathrm{XX}$ & $\mathrm{XX}$ \\
\hline
\end{tabular}

$$
\text { Overall accuracy }=\frac{\left(\sum^{i=\text { geomorphic setting }} p_{i j}\right)}{p_{++}},
$$

where overall accuracy is the sum of all proportions along the diagonal of the contingency table $\left(p_{i j}\right)$ divided by the sum of all row totals $(p++$; here, 1$)$. We also determined the amount of chance agreement between the in-situ classification and raster layer according to the following equation:

$$
\text { Chance agreement }=\sum_{i=j}^{\text {geomorphic setting }} p_{i+} \times p_{+j}
$$

where chance agreement is the sum of the product of the corresponding row $(p i+)$ and column $(p+j)$ totals. Finally, we calculated Cohen's kappa, which scales from 0 (random correlation) to 1 (perfect accuracy), as follows:

$$
k a p p a=\frac{\text { overall accuracy }- \text { chance agreement }}{1-\text { chance agreement }} .
$$

This coefficient was previously recommended as the optimal standardized statistic for assessing thematic accuracy because it incorporates chance agreement between classes
(Foody, 2002). Landis and Koch (1977) suggest the following accuracy thresholds: poor accuracy, kappa $=0$; fair accuracy, $0<$ kappa $\leq 0.4$; moderate accuracy, $0.4<$ kappa $\leq 0.6$; substantial accuracy, $0.6<\mathrm{kappa} \leq 0.8$; and almost perfect accuracy, kappa $>0.8$. This analysis was repeated separately for each variable (geomorphic setting [table 7], substrate type [table 8], vegetation type [table 9], and vegetation density [table 10]).

According to this validation exercise, we had an overall accuracy rate of 47 percent (kappa $=0.31$; table 7 ) for geomorphic setting, 97 percent (kappa $=0.94$; table 8 ) for substrate type, 94 percent (kappa $=0.89$; table 9 ) for vegetation type, and 86 percent (kappa $=0.77$; table 10) for vegetation density. For geomorphic setting, the most frequent errors occurred when backshore areas were misclassified in the raster layer as either beach or dune; dunes were misclassified as washover or barrier interior; washovers were misclassified as beach, backshore, dune, or barrier interior; and when areas in the barrier interior were misclassified as dune (table 7). In the vegetation type raster, areas lacking vegetation were most frequently misclassified as being herbaceous or vice versa (table 9). The largest sources of error in the vegetation density raster were misclassifications where areas of moderate vegetation we classified as having no vegetation, areas with no vegetation were classified as having sparse vegetation, and areas of sparse vegetation were classified as having moderate vegetation (table 10). The substrate type layer had few errors and no systemic errors (table 8). 
Table 8. Contingency table for validating substrate type raster layers created for each study area used to validate spatial analyses.

[For validation, we used biogeomorphic characteristics observed in situ at point locations contained in the iPlover dataset available in Sturdivant and others (2016). Cell values indicate the proportion of points that were classified as column $j$ (based on the remotely-classified raster layer) and as row $i$ (based on in-situ observations). Cell values along the diagonal (gray shading) indicate the proportion of points classified correctly in the raster layer. XX, not applicable]

\begin{tabular}{lcccccc}
\hline \multirow{2}{*}{$\begin{array}{c}\text { In-situ } \\
\text { classification }\end{array}$} & Sand & $\begin{array}{c}\text { Shell/ } \\
\text { gravel/ } \\
\text { cobble }\end{array}$ & Mud/peat & Water & $\begin{array}{c}\text { Revelop- } \\
\text { ment }\end{array}$ & Row total \\
\cline { 2 - 7 } & & 0.01 & 0.01 & 0.00 & 0.00 & 0.30 \\
\hline Sand & 0.28 & 0.64 & 0.00 & 0.00 & 0.00 & 0.65 \\
Shell/gravel/cobble & 0.01 & 0.00 & 0.04 & 0.00 & 0.00 & 0.04 \\
Mud/peat & 0.00 & 0.00 & 0.00 & 0.00 & 0.00 & 0.01 \\
Water & 0.01 & 0.00 & 0.00 & 0.00 & 0.01 & 0.01 \\
Development & 0.00 & 0.65 & 0.05 & 0.00 & 0.01 & $\mathrm{XX}$ \\
Column total & 0.29 & $\mathrm{XX}$ & $\mathrm{XX}$ & $\mathrm{XX}$ & $\mathrm{XX}$ & $\mathrm{XX}$ \\
Overall accuracy & 0.97 & $\mathrm{XX}$ & $\mathrm{XX}$ & $\mathrm{XX}$ & $\mathrm{XX}$ & $\mathrm{XX}$ \\
Chance agreement & 0.51 & $\mathrm{XX}$ & $\mathrm{XX}$ & $\mathrm{XX}$ & $\mathrm{XX}$ & $\mathrm{XX}$ \\
\hline Kappa coefficient & 0.94 & & & & & \\
\hline
\end{tabular}

Table 9. Contingency table for validating vegetation type raster layers created for each study area used to validate spatial analyses.

[For validation, we used biogeomorphic characteristics observed in situ at point locations contained in the iPlover dataset available in Sturdivant and others (2016). Cell values indicate the proportion of points that were classified as column $j$ (based on the remotely-classified raster layer) and as row $i$ (based on in-situ observations). Cell values along the diagonal (gray shading) indicate the proportion of points classified correctly in the raster layer. XX, not applicable]

\begin{tabular}{lcccccc}
\hline \multirow{2}{*}{$\begin{array}{c}\text { In-situ } \\
\text { classification }\end{array}$} & None & $\begin{array}{c}\text { Herba- } \\
\text { ceous }\end{array}$ & Shrub & Forest & $\begin{array}{c}\text { Develop- } \\
\text { ment }\end{array}$ & Row total \\
\cline { 2 - 7 } None & 0.40 & 0.04 & 0.00 & 0.00 & 0.00 & 0.44 \\
Herbaceous & 0.02 & 0.50 & 0.00 & 0.00 & 0.00 & 0.52 \\
Shrub & 0.00 & 0.00 & 0.02 & 0.00 & 0.00 & 0.02 \\
Forest & 0.00 & 0.00 & 0.00 & 0.01 & 0.00 & 0.01 \\
Development & 0.00 & 0.00 & 0.00 & 0.00 & 0.01 & 0.01 \\
Column total & 0.42 & 0.54 & 0.02 & 0.01 & 0.01 & $\mathrm{XX}$ \\
Overall accuracy & 0.94 & $\mathrm{XX}$ & $\mathrm{XX}$ & $\mathrm{XX}$ & $\mathrm{XX}$ & $\mathrm{XX}$ \\
Chance agreement & 0.47 & $\mathrm{XX}$ & $\mathrm{XX}$ & $\mathrm{XX}$ & $\mathrm{XX}$ & $\mathrm{XX}$ \\
Kappa coefficient & 0.89 & $\mathrm{XX}$ & $\mathrm{XX}$ & $\mathrm{XX}$ & $\mathrm{XX}$ & $\mathrm{XX}$ \\
\hline
\end{tabular}


Table 10. Contingency table for validating vegetation density raster layers created for each study area used to validate spatial analyses.

[For validation, we used biogeomorphic characteristics observed in situ at point locations contained in the iPlover dataset available in Sturdivant and others (2016). Cell values indicate the proportion of points that were classified as column $j$ (based on the remotely-classified raster layer) and as row $i$ (based on in-situ observations). Cell values along the diagonal (gray shading) indicate the proportion of points classified correctly in the raster layer. XX, not applicable]

\begin{tabular}{lcccccc}
\hline \multirow{2}{*}{$\begin{array}{c}\text { In-situ } \\
\text { classification }\end{array}$} & None & $\begin{array}{c}\text { Herba- } \\
\text { ceous }\end{array}$ & Shrub & Forest & $\begin{array}{c}\text { Develop- } \\
\text { ment }\end{array}$ & $\begin{array}{c}\text { Row } \\
\text { total }\end{array}$ \\
\cline { 2 - 7 } & 0.40 & 0.04 & 0.00 & 0.00 & 0.00 & 0.44 \\
None & 0.01 & 0.38 & 0.01 & 0.00 & 0.00 & 0.40 \\
Herbaceous & 0.06 & 0.00 & 0.04 & 0.00 & 0.00 & 0.10 \\
Shrub & 0.01 & 0.00 & 0.00 & 0.03 & 0.00 & 0.04 \\
Forest & 0.00 & 0.00 & 0.00 & 0.00 & 0.01 & 0.01 \\
\cline { 2 - 7 } Development & 0.48 & 0.42 & 0.05 & 0.03 & 0.01 & $\mathrm{XX}$ \\
Column total & 0.86 & $\mathrm{XX}$ & $\mathrm{XX}$ & $\mathrm{XX}$ & $\mathrm{XX}$ & $\mathrm{XX}$ \\
Overall accuracy & 0.39 & $\mathrm{XX}$ & $\mathrm{XX}$ & $\mathrm{XX}$ & $\mathrm{XX}$ & $\mathrm{XX}$ \\
Chance agreement & 0.39 & $\mathrm{XX}$ & $\mathrm{XX}$ & $\mathrm{XX}$ & $\mathrm{XX}$ & $\mathrm{XX}$ \\
Kappa coefficient & 0.77 & & & & & \\
\hline
\end{tabular}

Errors in these analyses likely came from one or more of three different sources: (1) errors in the in-situ biogeomorphic classification (that is, errors in the points used for validation); (2) time mismatches between the lidar imagery, orthoimagery, and validation points; and (3) author errors in the supervised classification or visual interpretation of orthoimagery. In the first case, Thieler and others (2016) analyzed the same points used for validation in this study and found some discrepancy between the original field users' in-situ biogeomorphic classifications and experts' classifications of those same land cover conditions. This was especially true for classifications of geomorphic setting, where there was disagreement between users and experts for 42 percent of all test points used in that study (Thieler and others, 2016). Discrepancies between users and experts were less prevalent for substrate type (disagreement for 20 percent of points used in that study), vegetation type (16-percent disagreement), and vegetation density (23-percent disagreement; Thieler and others, 2016). This suggests that some of the measured error in the raster layers described in this report resulted from error in the validation points themselves, not in the classification or creation of raster layers.

This may be especially true for the raster layer for geomorphic setting, which was associated with both the lowest accuracy in this study and the highest level of disagreement in Thieler and others (2016).

In the second case (mismatches between lidar imagery, orthoimagery, and validation points), both lidar datasets and orthoimagery were used to create the geomorphic setting raster layer. Lidar analyses resulted in points for the location of the
MHW shoreline, foredune toe, and foredune crest (Stockdon and others, 2009; Doran and others, 2017), which we used to delineate boundaries between the beach and backshore, between the backshore and dunes, and between dunes and the barrier interior. Visual interpretation of orthoimagery was used to hand-digitize the boundaries of washovers, marsh, and areas inland of dune complexes. Orthoimagery was also used for the supervised classification of substrate type, vegetation type, and vegetation density layers. In some instances, there were differences in when the lidar and the orthoimagery were collected for a single site, ranging from several months to a year. Furthermore, the dates on which these remotely sensed datasets were captured often differed from when the in-situ validation points were characterized. In these highly dynamic environments, conditions can change drastically in a matter of days, and error could have been introduced in the raster layers if the biogeomorphology of a barrier island changed substantially between the time remotely sensed datasets were captured and when in-situ validation points were classified.

Finally, error could have also arisen because of incorrect interpretations in the visual assessment of orthoimagery or in the supervised classification. It was necessary to manually interpret orthoimagery in order to create the geomorphic setting, substrate type, vegetation type, and vegetation density layers, and this interpretation adds a degree of subjectivity to the process. This interpretation occurred as we hand-digitized boundaries or created classification polygons used in the supervised classification routine. 


\section{Data Access and Metadata}

Intermediate datasets and $\mathrm{BN}$ datasets generated according to the methodology described in this report are published as a separate USGS data release (Sturdivant and others, 2019). Further information about the project, including specific study sites, can be found at https://woodshole.er.usgs.gov/project-pages/ beach-dependent-shorebirds/. Programming code is also made available separately (https://doi.org/10.5066/P915UYMY). Federal Geographic Data Committee-compliant metadata are provided with each of these datasets. Metadata include initial data sources (for example, lidar, orthoimagery) used to produce the datasets, acquisition dates of initial data sources, spatial and temporal resolution, data quality control, and specific process steps that would be necessary to recreate datasets. Metadata also include relevant references, such as peerreviewed publications, reports, or websites that provide additional information on initial data sources or processing steps.

\section{References Cited}

Braatz, B.V., and Aubrey, D.G., 1987, Recent relative sea-level change in eastern North America, in Nummedal, D., Pilkey, O.H., and Howard, J.D., eds., Sea-level fluctuation and coastal evolution: Society of Economic Paleontologists and Mineralogists Special Publication no. 41, p. 29-46. [Also available at https://doi.org/10.2110/pec.87.41.0029.]

Church, J.A., Clark, P.U., Cazenave, A., Gregory, J.M., Jevrejeva, S., Levermann, A., Merrifield, M.A., Milne, G.A., Nerem, R.S., Nunn, P.D., Payne, A.J., Pfeffer, W.T., Stammer, D., and Unnikrishnan, A.S., 2013, Sea-level change, in Stocker, T.F., Qin, D., Plattner, G.-K., Tignor, M., Allen, S.K., Boschung, J., Nauels, A., Xia, Y., Bex, V., and Midgley, P.M., eds., Climate change 2013-The physical science basis. Contribution of Working Group I to the Fifth Assessment Report of the Intergovernmental Panel on Climate Change: Cambridge, United Kingdom, Cambridge University Press, p. 1137-1216.

Cohen, J.B., and Fraser, J.D., 2010, Piping plover foraging distribution and prey abundance in the pre-laying period: The Wilson Journal of Ornithology, v. 122, no. 3, p. 578582. [Also available at https://doi.org/10.1676/09-145.1.]

Cohen, J.B., Houghton, L.M., and Fraser, J.D., 2009, Nesting density and reproductive success of piping plovers in response to storm- and human-created habitat changes: Wildlife Monographs, v. 173, no. 1, p. 1-24. [Also available at https://doi.org/10.2193/2007-553.]
Cohen, J.B., Wunker, E.H., and Fraser, J.D., 2008, Substrate and vegetation selection by nesting piping plovers: The Wilson Journal of Ornithology, v. 120, no. 2, p. 404-407. [Also available at https://doi.org/10.1676/06-169.1.]

Courchamp, F., Hoffmann, B.D., Russell, J.C., Leclerc, C., and Bellard, C., 2014, Climate change, sea-level rise, and conservation-Keeping island biodiversity afloat: Trends in Ecology \& Evolution, v. 29, no. 3, p. 127-130. [Also available at https://doi.org/10.1016/j.tree.2014.01.001.]

Davis, R.A., Jr., 1985, Beach and nearshore zone, in Davis, R.A., Jr., ed., Coastal sedimentary environments: New York, N.Y., Springer-Verlag, p. 379-444. [Also available at https://doi.org/10.1007/978-1-4612-5078-4_6.]

Davis, R.A., Jr., ed., 1994, Geology of Holocene barrier island systems: Berlin, Germany, Springer-Verlag, 464 p. [Also available at https://doi.org/10.1007/978-3-642-78360-9.]

Doran, K.S., Long, J.W., Birchler, J.J., Brenner, O.T., Hardy, M.W., Morgan, K.L.M., Stockdon, H.F., and Torres, M.L., 2017, Lidar-derived beach morphology (dune crest, dune toe, shoreline) for U.S. sandy coastlines: U.S. Geological Survey data release. [Also available at https://doi.org/10.5066/F7GF0S0Z.]

FitzGerald, D.M., Fenster, M.S., Argow, B.A., and Buynevich, I.V., 2008, Coastal impacts due to sea-level rise: Annual Review of Earth and Planetary Sciences, v. 36, p. 601-647. [Also available at https://doi.org/10.1146/ annurev.earth.35.031306.140139.]

Foody, G.M., 2002, Status of landcover classification accuracy assessment: Remote Sensing of Environment, v. 80, no. 1, p. 185-201. [Also available at https://doi.org/10.1016/ S0034-4257(01)00295-4.]

Fraser, J.D., Keane, S.E., and Buckley, P.A., 2005, Prenesting use of intertidal habitats by piping plovers on South Monomoy Island, Massachusetts: Journal of Wildlife Management, v. 69, no. 4, p. 1731-1736. [Also available at https://doi.org/10.2193/0022-541X(2005)69

[1731:PUOIHB]2.0.CO;2.]

Galbraith, H., Jones, R., Park, R., Clough, J., Herrod-Julius, S., Harrington, B., and Page, G., 2002, Global climate change and sea-level rise-Potential losses of intertidal habitat for shorebirds: Waterbirds, v. 25, no. 2, p. 173-183. [Also available at https://doi.org/10.1675/ 1524-4695(2002)025[0173:GCCASL]2.0.CO;2.]

Gieder, K.D., Karpanty, S.M., Fraser, J.D., Catlin, D.H., Gutierrez, B.T., Plant, N.G., Turecek, A.M., and Thieler, E.R., 2014, A Bayesian network approach to predicting nest presence of the federally-threatened piping plover (Charadrius melodus) using barrier island features: Ecological Modelling, v. 276, p. 38-50. [Also available at https://doi.org/10.1016/j.ecolmodel.2014.01.005.] 
Godfrey, P.J., 1976, Comparative ecology of East Coast barrier islands-Hydrology, soil, vegetation, in Barrier islands and beaches-Technical proceedings of the 1976 Barrier Islands Workshop, Annapolis, Maryland, May 17-18, 1976: Washington, D.C., The Conservation Foundation, p. 5-31.

Gornitz, V., and Lebedeff, S.J., 1987, Global sea-level changes during the past century, in Nummedal, D., Pilkey, O.H., and Howard, J.D., eds., Sea-level fluctuation and coastal evolution: Society of Economic Paleontologists and Mineralogists Special Publication no. 41, p. 3-16. [Also available at https://doi.org/10.2110/pec.87.41.0003.]

Gutierrez, B.T., Plant, N.G., Pendleton, E.A., and Thieler, E.R., 2014, Using a Bayesian network to predict shorelinechange vulnerability to sea-level rise for the coasts of the United States: U.S. Geological Survey Open-File Report 2014-1083, 26 p. [Also available at https://doi.org/10.3133/ ofr20141083.]

Gutierrez, B.T., Plant, N.G., and Thieler, E.R., 2011, A Bayesian network to predict coastal vulnerability to sea level rise: Journal of Geophysical Research, v. 116, F02009, p. 1-15. [Also available at https://doi.org/10.1029/2010JF001891.]

Gutierrez, B.T., Plant, N.G., Thieler, E.R., and Turecek, A., 2015, Using a Bayesian network to predict barrier island geomorphologic characteristics: Journal of Geophysical Research, Earth Surface, v. 120, p. 2452-2475. [Also available at https://doi.org/10.1002/2015JF003671.]

Gutierrez, B.T., Williams, S.J., and Thieler, E.R., 2007, Potential for shoreline changes due to sea-level rise along the U.S. mid-Atlantic region: U.S. Geological Survey Open-File Report 2007-1278, 30 p. [Also available at https://pubs.er.usgs.gov/publication/ofr20071278.]

Hapke, C.J., Himmelstoss, E.A., Kratzmann, M.G., List, J.H., and Thieler, E.R., 2011, National assessment of shoreline change- - Historical change along the New England and Mid-Atlantic coasts: U.S. Geological Survey Open-File Report 2010-1118, 57 p. [Also available at https://pubs.usgs.gov/of/2010/1118/.

Hauer, M.E., Evans, J.M., and Mishra, D.R., 2016, Millions projected to be at risk from sea-level rise in the continental United States: Nature Climate Change, v. 6, p. 691-695. [Also available at https://doi.org/10.1038/nclimate2961.]

Himmelstoss, E.A., Kratzmann, M., Hapke, C., Thieler, E.R., and List, J., 2010, The national assessment of shoreline change-A GIS compilation of vector shorelines and associated shoreline change data for the New England and Mid-Atlantic Coasts. U.S. Geological Survey Open-File Report 2010-1119. [Also available at https://pubs.usgs.gov/ of/2010/1119.]

Johnson, D.W., 1919, Shore processes and shoreline development: New York, N.Y., John Wiley and Sons, 584 p.
Jones, L.K., 1997, Piping plover habitat selection, home range, and reproductive success at Cape Cod National Seashore, Massachusetts: Amherst, Mass., University of Massachusetts, M.Sc. thesis, 96 p.

Kisiel, C., 2009, The spatial and temporal distribution of piping plovers in New Jersey-1987-2007: New Brunswick, N.J., Rutgers University, M.Sc. thesis, 82 p.

Kopp, R.E., Kemp, A.C., Bittermann, K., Horton, B.P., Donnelly, J.P., Gehrels, W.R., Hay, C.H., Mitrovica, J.X., Morrow, E.D., and Rahmstorf, S., 2016, Temperature-driven global sea-level variability in the Common Era: Proceedings of the National Academy of Sciences of the United States of America, v. 113, no. 11, p. E1434-E1441. [Also available at https://doi.org/10.1073/pnas.1517056113.]

Landis, J.R., and Koch, G.G., 1977, The measurement of observer agreement for categorical data: Biometrics, v. 33, no. 1, p. 159-174. [Also available at https://doi.org/10.2307/2529310.]

Lea, C., and Curtis, A.C., 2010, Thematic accuracy assessment procedures - National Park Service vegetation inventory, version 2.0: National Park Service National Resource Report NPS/2010/NRR-2010/204, 90 p.

Leatherman, S.P., 1983, Barrier dynamics and landward migration with Holocene sea-level rise: Nature, v. 301, p. 415417. [Also available at https://doi.org/10.1038/301415a0.]

Leatherman, S.P., Williams, A.T., and Fisher, J.S., 1977, Overwash sedimentation associated with a large-scale northeaster: Marine Geology, v. 24, no. 2, p. 109-121. [Also available at https://doi.org/10.1016/0025-3227(77)90004-4.]

Lentz, E.E., Thieler, E.R., Plant, N.G., Stippa, S.S., Horton, R.M., and Gesch, D.B., 2016, Evaluation of dynamic coastal response to sea-level rise modifies inundation likelihood: Nature Climate Change, v. 6, no. 7, p. 696-701. [Also available at https://doi.org/10.1038/nclimate2957.]

Maslo, B., Burger, J., and Handel, S.N., 2012, Modeling foraging behavior of piping plovers to evaluate habitat restoration success: The Journal of Wildlife Management, v. 76, no. 1, p. 181-188. [Also available at https://doi.org/10.1002/ jwmg.210.]

Maslo, B., Handel, S.N., and Pover, T., 2011, Restoring beaches for Atlantic Coast piping plovers (Charadrius melodus) — A classification and regression tree analysis of nest-site selection: Restoration Ecology, v. 19, no. 201, p. 194-203. [Also available at https://doi.org/10.1111/ j.1526-100X.2010.00709.x.] 
McGranahan, G., Balk, D., and Anderson, B., 2007, The rising tide-Assessing the risks of climate change and human settlements in low elevation coastal zones: Environment and Urbanization, v. 19, no. 1, p. 17-37. [Also available at https://doi.org/10.1177/0956247807076960.]

Melillo, J., Richmond, T., and Yohe, G., eds., 2014, Climate change impacts in the United States-The third national climate assessment: U.S. Global Change Research Program, 841 p., https://doi.org/10.7930/J0Z31WJ2.

Menon, S., Soberón, J., Li, X., and Peterson, A.T., 2010, Preliminary global assessment of terrestrial biodiversity consequences of sea-level rise mediated by climate change: Biodiversity and Conservation, v. 19, no. 6, p. 1599-1609. [Also available at https://doi.org/10.1007/ s10531-010-9790-4.]

Morton, R.A., Paine, J.G., and Gibeaut, J.C., 1994, Stages and durations of post-storm beach recovery, southeastern Texas coast, U.S.A: Journal of Coastal Research, v. 10, no. 4, p. 884-908.

Morton, R.A., and Sallenger, A.H., Jr., 2003, Morphological impacts of extreme storms on sandy beaches and barriers: Journal of Coastal Research, v. 19, no. 3, p. 560-573.

National Oceanic and Atmospheric Administration, 2018, Vertical datum transformation: National Oceanic and Atmospheric Administration database, accessed September 4, 2018, at https://vdatum.noaa.gov/.

Neuendorf, K.K.E., Mehl, J.P., Jr., and Jackson, J.A., eds., 2011, Glossary of geology (5th ed.): Alexandria, Va., The American Geosciences Institute, 783 p.

Nicholls, R.J., and Cazenave, A., 2010, Sea-level rise and its impacts on coastal zones: Science, v. 328 , no. 5985 , p. 1517-1520. [Also available at https://doi.org/10.1126/ science.1185782.]

Oertel, G.F., 1985, The barrier island system: Marine Geology, v. 63, no. 1-4, p. 1-18. [Also available at https://doi.org/10.1016/0025-3227(85)90077-5.]

Plant, N.G., and Stockdon, H.F., 2012, Probabilistic prediction of barrier island response to hurricanes: Journal of Geophysical Research: Earth Surface, v. 117, F03015, p. 1-17. [Also available at https://doi.org/10.1029/2011JF002326.]

Rice, T.M., 2015a, Inventory of habitat modifications to sandy beaches in the US Atlantic Coast breeding range of the piping plover prior to Hurricane Sandy-Maine to the North Shore and Peconic Estuary of New York: Terwilliger Consulting, Inc., report submitted to the U.S. Fish and Wildlife Service, $84 \mathrm{p}$.
Rice, T.M., 2015b, Storm-induced habitat modifications caused by Hurricane Sandy within the U.S. Atlantic Coast breeding range of the piping plover (Charadrius melo$d u s)$ : Terwilliger Consulting, Inc., report submitted to the U.S. Fish and Wildlife Service, 47 p.

Sallenger, A.H., Jr., Doran, K.S., and Howd, P.A., 2012, Hotspot of accelerated sea-level rise on the Atlantic coast of North America: Nature Climate Change, v. 2, p. 884-888. [Also available at https://doi.org/10.1038/nclimate1597.]

Stockdon, H.F., Doran, K.S., and Sallenger, A.H., Jr., 2009, Extraction of lidar-based dune crest elevations for use in examining vulnerability of beaches to inundation during hurricanes: Journal of Coastal Research, v. SI 53, p. 59-65. [Also available at https://doi.org/10.2112/SI53-007.1.]

Stockdon, H.F., Doran, K.S., Thompson, D.M., Sopkin, K.L., Plant, N.G., and Sallenger, A.H., Jr., 2012, National assessment of hurricane-induced coastal erosion hazards - Gulf of Mexico: U.S. Geological Survey Open File Report 20121084, 51 p. [Also available at https://pubs.er.usgs.gov/ publication/ofr20121084.]

Strauss, E., 1990, Reproductive success, life history patterns, and behavioral variation in a population of piping plovers subjected to human disturbance: Boston, Mass., Tufts University, Ph.D. dissertation, $142 \mathrm{p}$.

Sturdivant, E.J., 2019, Bi-transect-extractor: U.S. Geological Survey software code, https://doi.org/10.5066/P915UYMY.

Sturdivant, E.J., Thieler, E.R., Zeigler, S.L., Winslow, L.A., Hines, M.K., Read, J.S., and Walker, J.I., 2016, Biogeomorphic classification and images of shorebird nesting sites on the U.S. Atlantic coast: U.S. Geological Survey data release, https://doi.org/10.5066/F70V89X3.

Sturdivant, E.J., Zeigler, S.L., Gutierrez, B.T., and Weber, K.M., 2019, Barrier island geomorphology and shorebird habitat metrics - four sites in New York, New Jersey, and Virginia, 2010-2014: U.S. Geological Survey data release, https://doi.org/10.5066/P944FPA4.

Sweet, W.V., Kopp, R.E., Weaver, C.P., Obeysekera, J., Horton, R.M., Thieler, E.R., and Zervas, C., 2017, Global and regional sea level rise scenarios for the United States: National Oceanic and Atmospheric Administration Technical Report NOS CO-OPS 083, 75 p.

Thieler, E.R., Zeigler, S.L., Winslow, L.A., Hines, M.K., Read, J.S., and Walker, J.I., 2016, Smartphone-based distributed data collection enables rapid assessment of shorebird habitat suitability: PLoS One, v. 11, no. 11, e0164979. [Also available at https://doi.org/10.1371/journal.pone.0164979.] 
Titus, J.G., Anderson, K.E., Cahoon, D.R., Gesch, D.B., Gill, S.K., Gutierrez, B.T., Thieler, E.R., and Williams, S.J., 2009, Coastal sensitivity to sea-level rise-A focus on the mid-Atlantic region: U.S. Climate Change Science Program Synthesis and Assessment Product 4.1, 298 p.

U.S. Commission on Ocean Policy, 2004, Final report-An ocean blueprint for the 21 st century: Washington, D.C., U.S. Commission on Ocean Policy, 676 p.

U.S. Department of Agriculture, 2015, The PLANTS Database: USDA's National Resources Conservation Service database, accessed January 13, 2014, at https://www.plants.usda.gov.

U.S. Fish and Wildlife Service, 2014, North Atlantic Coast Comprehensive Study-Biological resources and habitats vulnerable to sea level rise and storm activity in the northeast United States: U.S. Fish and Wildlife Service report, $119 \mathrm{p}$.
Weber, K.M., List, J.H., and Morgan, K.L.M., 2005, An operational mean high water datum for determination of shoreline position from topographic lidar data: U.S. Geological Survey Open-File Report 2005-1027. U.S. Geological Survey. [Also available at https://pubs.usgs.gov/of/2005/1027/.]

Zeigler, S.L., Thieler, E.R., Gutierrez, B.T., Plant, N.G., Hines, M., Fraser, J.D., Catlin, D.H., and Karpanty, S.M., 2017, Smartphone technologies and Bayesian networks to assess shorebird habitat selection: Wildlife Society Bulletin, v. 41, no. 4, p. 666-677. [Also available at https://doi.org/10.1002/ wsb.820.] 
For more information about this report, contact: Director, Woods Hole Coastal and Marine Science Center U.S. Geological Survey 384 Woods Hole Road

Quissett Campus

Woods Hole, MA 02543-1598

WHSC_science_director@usgs.gov (508) 548-8700 or (508) 457-2200

or visit our website at https://woodshole.er.usgs.gov

Publishing support provided by the Pembroke Publishing Service Center 
ד.:

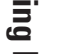

$\frac{7}{2}$

西

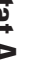

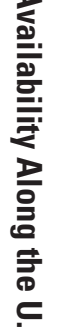

is

全

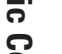

政

1

产

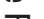

(1)

$\widetilde{\widetilde{\sigma}}$

家

市 